\title{
OTELCILERIN MES'ULIYETI
}

\section{Doçent Dr. Holukk TANDOGAN}

\section{I - Mes'uliyetin Mucip Sebepleri Ve Hukuki Mahiyeti.}

sebepler.

1. Otelcilenin mes'uliyetinin hususî surette tanzimini icap ettiren:

BK. md. 478 cümle 1 e tevfikan "otelciler, hancılar nazil olan yolculann getirdikJeri eşyanın duçar olduğu telef ve hasar ve sitkatten, zarann bizzat yolcuya veya onu ziyarete gelen veya refakatinde bulunan kimseye isnadt kabil olduğunu veya mücbir sebeplerden neş'et ettiğini veya tevdi olunan ş€yin mahiyetinden mütevellid bulunduğunu isbat etmedikçe mes'uldür.” Müşahede olunduğu üzere burada, otelcinin kusuruna istinad etmeyen bir objektif mes'uliyet hali bahis mevzuudur. Otelcinin böylt ağır bir mes'uliyete tabi tutulmas Roma Hukukundan gelen bir esastır. Modern hukuk sistemlerinin hemen hepsinde de teferruata ait bazı farklarla yer almış bulunan bu esasın kabulü için şu mucip sebepler ileri sü-rülmüş̧tür:

a) Roma Hukukunda hancılann ağır mes'uljyeti, - onlann iyi şöb-. ret sahibi olmadıklan ve ekseriya haydutlarla işbirliği yaparak müşłerileri soyduklan gibi mülâhazalarla haklı gösteriliyordu ${ }^{1}$. Bittabiî zama-nımızda bu gibi mülâhazalar hatı̛a gelemez. Aşağıda arzedeceğimiz: veçhile modern hukuk sistemlerinde, otelcinin ağır mes'uliyeti tamamen bașka mucip sebeplerle izah olunmaktadır. Bu itibarla Roger Secrétan'm son senelerde bir içtihad tahlilinde müdafaa ettiği görüşe ${ }^{2}$ iştírak etmemiz.

1) Bk. Jean Chaubert, La responsabilité civile de l'hôtelier a raison des effets apportés par le voyageur, thèse Lausanne 1914, sh. 15; von Versam Paul Buchli, Die Haftung der Gast-und Stall-wirte nach dem schweiz. Obligationen-. recht, Diss. Bern 1932, sh. 11; Roger Secrétan, Note surla responsabilíté du garagiste et sur celle de l'hôteljer pour les voitures garées dans l'hôtel, JdT, 1951, sh. 182; Pièrre Pétermann, La responsabilité civile des hôteliers pour les choses: apportées par des clients, Lausanne 1955, sh. 1-2.

2) JđT, 1951, sh. 183. Petermann da (sh.3) Secrêtan'ın görüşũnü tasvip: etmektedir. 
:mümkün değildir. Secrétan'a nazaran, bugün artık otelciler de dürüst ve diğer tacirler kadar hürmete lâyı vatandaşlardır; onların akdî mes'uliyet hakkındaki umumi hükümlerin emrettiğinden daha ağır bir muameleye tabi tutulmalan, bir nevi smıt hukuku yaratmak neticesini doğurmuştur; bu teessüfe şayan neticeyi bertaraf etmek için otelcinin mes'uliyeti hak. kındaki, zamanımızın jeaplanna uygun olmayan, hususî hükümler kanundan çıkarılmalıdır. Kanaatimizce, bugün artık otelcilerin dürüstlü̆ğ.̈ üzerinde herhangi bir şüpheye mahal yoksa da, onlann mes'uliyetini hususî surette tanzim etmek zarureti inkâr edilemez.

b) Bazı müellifler:3 bu zarureti " "ihdas edilen tehlike" fikrine istinad ettirmektedirler. Filhakika bir otel işletmesi, otele inen yolcuların eşyalarına bizzat nezaret güçlüğü, birçok yardımcı șahıslara müracaat edilmesi, ne otelcinin tanıdığ ne de birbirlerinj tanıyan çeșitli insanların otelde bir araya gelmesi yüzünden yolcuların eşyasının telefi hasara uğraması veya çalınması tehlikelerini arttırı. Bu tehlikelerin neticesine oteli açmakla bunları ihdas eden ve otelin getirdiği ekonomik menfaatlerden faydalanan otelcinin katlanması münasip olur.

Binaenaleyh burada illiyete müstenid mes'uliyetin hususi bir nevii karşısında bulunulur'.

c) Diğer bir kısım müelliflerin fikrince ise ${ }^{5}$, otelcinin mes'uliyeti :illiyete müstenid bir mes'uliyet vasfını taşımamaktadır; otelci muayyen bir sebebin ona uygun illiyet rabitastyla ba.ğl bütün neticelerinden mes'ul de.y̆iidir; meselâ, eşyanın otele getirilmesi ile çalınması arasında bir uygun

3) Max Rümelin, Zufall im Recht, Freiburg i. Br, und Lejpzig, 1896, sh 31 ve müt; Silvio Giovanoli, Force majeure et cas fortuit en matière d'inexécution des obligations, selon le Code des obligations suisse, thèse Genève 1933, sh. 217; Erich Volkmar, Vis maior und Betriebsgefahr, Rechts-und Staatswissenschatfliche Studien, Heft 9, Berlin 1900, sh. 51 ve müt; Virgile Rossel, Manuel du droit féderal des obligations, t.I,2. éd. Lausanne-Genève, 1920, sh. 558; Andreas B. Schwarz, Borçlar Hukuku Dersleri, cilt I, Istanbul 1948, sh, 104.

4) Theo Guhl, Le droit fédéral des obligations, trad, par René Des Gouttes, "Zurich 1947, sh. 336; H. Avni Göktürk, Borçlar Hukuku, ikinci kısım: Akdju muhtelif nevileri, Ankara 1951, sh. 592; Fritz Autenrieth-Gander, FJS, no. 661. :sh. 1; Pëtermann, sh. 15.

5) Emil Wilhelm Stark, Beitrag zur Theorie der Entlastungsgründe în Haftpflichtrecht, Diss. Zürich 1946, sh. 152 ve müt.; Ad. Exner, Der Begriff 'der höheren Gewalt (vis major) im römischen und heutigen Verkehrsrecht, Wien 1883, sh. 46; H. Becker, Obligationenrecht, II. Abt.: Die einzelnen Vertragsverhältnisse, Bern 1934, Art. 487, Nr. 31. 
illiyet rabıtası bulunduğu iddia edilemez; otelci, sadece kanunda saylan. lardan gayn bütün sebeplerden husule gelen muayyen neticeler jc̣in mes'. uldür; yani burada bir netice mes'uliyeti mevcutttur. Eşyanın telefi, hasara uğraması veya çalınması neticesini, bizzat yolcu, onun ziyaretçileri veya refakatinde bulunanlar, yahut mücbir bir sebep veya eşyanın kendi mahiyeti husule getirmedikçe, otelci uğranulan zaran tazminle mükelleftir.

Otel işletmesi, otele getirilen eşya için yeni tehlikeler ihdas etmez; yalnız eşyanın otelde telefi, hasara uğraması veya çalınması halinde, buna sebebiyet veren şahsın kim olduğunun ve onun kusurunun tesbiti, otelde çeşitli kimselerin bulunması ve yolcunun eşyasına devamlı olarak nezaret edememesi yüzünden müssküldür; bundan başka, müșteri otelci ile aralarnndaki bir mukaveleye istinad ederse, bu mukavelenin ve otelcinin mu. kaveleye aykun hareketinin mevcudiyetini isbat da her zaman kolay de ğildir. Binaenaleyh, otelcinin ağır mes'uliyeti, sadece yolcunun bahsi geçen hususlan isbat bakımından karşılaşacağı gïiçükleri bertaraf etmel: için kabul edilmiştir.

Bu görüş tarzına karşı Rümelinn, yolcunun isbat bakımından uğrayacağı güçlüğü, isbat külfetini ters çevirmek suretile izale etmek mümkün olacağını ve ağır mes'uliyetin kabulünün gayeyi aşan bir hal tarn teşkil edeceğini ileri sürmüştür. Fakat, ağır mes'uliyetin mesnedini is̉ał zorluğunda görenler Rümelin'nin tenkidine şöylece mukabele etmişlerdir ${ }^{\top}$ isbat külfeti ters çevrilse ve otelci kusuru olmadığını isbata mecbur kılınsa dahi, otelcinin bu husustaki isbatını çürütebilmek yolcu için çok müşkül, hatta ekseriya imkânsızdır; bu itibarla isbat külfetini ters çevirmek yolcuyu himaye için kifayet etmez.

d) Müelliflerin ekseriyetis, otelcinin ağır mes'uliyetini tek bir sebeple hakh göstermemekte, bu hususta gerek otel işletmesinin yarattığ tehlikeleri, gerekse yolcunun isbał külfeti bakımından uğrayacağı zorluklan bir arada ileri sürmektedirler. Bu sebeplere, otelcinin iktisaden yol. cudan daha kudretli olduğu, âmme menfaatinin otellerin emniyetli olma-

6) Sh. 29-30.

7) Stark, sh. 156-157.

8) Bk. Chaubert, sh. 27-32; Paul Buchli, sh. 11-12; Oser-Schönenberger, Kormmentar zum Obligationenrecht, 3. Teil, Zweite Auflage, Zürich 1945, Art. 487, Nr. 1 ve 28; Silvio Giovanoli, Zufall und höhere Gewalt im schweiz. Rechte, ZSR, N.F. 54 (1935), sh. 9 ve 29; Staudinger-Nipperdey, Kommentar zum BGB, II. Bd., 3. Teil, 10. Aufl. Berlin 1941, vor \& 701, Nr. 6; P. Macdonald: Die Ansprüche des Gastes aus dem Receptum des BGB, Diss Greifswald 1899, sh. 7-8. 
sını iktiza ettirdiği, ekseriyetle muvakkaten otelin bulunduğu yerde kalan yolcunun tazminat davasının çabuk neticelendirilmesinde menfaati bulursduğu, ağrr mes'uliyetin otelciyi daha ziyade dikkat göstermeğe sevkedeceği gibi mülâhazalar da ilâve olunmaktadır ${ }^{9}$.

2. Otelcilerin mes'uliyetinin hukukî mahiyeti.

Otelcilerin mes'uliyetinin akdi mahiyeti mi hajz olduğu yoksa dos̆. rudan doğruya kanundan mı neş'et ettiği doktrinde münakaşalıdır:

a) Bazı hukukçular, bu mes'uliyetin akdì mahiyet taşıdığı kanaa. tindedirler. Ancak mes'uliyetin istinad ettiği akdin hangisi olduğu hakkında aralarnda bir fikir birliği yoktur:

aa) Bu hukukçulardan bir kısmına göre ${ }^{10}$, bahis mevzuı mes'uliyetin temelini, otelci ile yolcu arasında aktedilen hususi tipte bur akitte bulmak mümkündür; bu akde otelcilik veya misafir kabulü mukavelesi (contrat d'hôtellerie, Gastaufnahmevertrag) ismi verilmektedir. Mezkûr mukavele mucibince, otelci, bir bedel mukabilinde yolcuya icar, hizmei, satış, vedia akitlerine has bazı edalarda bulunur; yolcuyu ağırlamak gayesiyle vapilan bu edalarn hepsinin bir araya gelmesinden yeni bir akit tipi ortaya çkar.

Otelicilik mukavelesi mefhumu șiddetle tenkid edilmiştir ${ }^{11}$. Filha. kika, bu mukavele kendisine has edalan ihtiva etmez; muhtelif tipte akitlerin bir gaye etrafinda toplanmasıyla ortaya çlkan mürekkep bir mukavele (contrat complexe) mahiyetini taşır; bu mukaveleyi diğerlerinden ayracak vasıflan tesbit etmek kabil olmadığ gibi, otelcinin mes'uliyetine müteallik hükümler haricinde mukaveleye tatbik edilecek hususî kaideler de mevcut değildir; binaenaleyh hiçbir prat:k faydası olmayan ve hudut. lan lâyıkıyla tesbit edilemeyen yeni bir akit tipi ortaya atmakta mâna yoktur; zaten Portekiz MK. (md. 1419-1423) müstesna, modern tedvin hareketlerin:n hiçbirinde böyle bir akit tipine ver verilmemiştir. Hülâsa, otelcinin mes'uliyetini, mevcudiyeti bu kadar ihtilâfh olan otelcilik mukavelesine istinad ettirmek isabetli olmaz; kaldı ki, bu mes'uliyet bazan

9) Bk. Stark'ın sh. 157 , not 88 ve 89 da zikrettiği müellifler.

10) Ezcümle : Rul, Le contrat d'hotellerie ou rapports juridiques entre I'hôtelier et le voyageur, thèse Paris 1906, sh. 48 ve müt.; G. Ernst, Der Gastaufnahmevertrag, Diss. Zürich 1903, sh. 20 ve müt., sh. 101. Pêtermann, sh. 15: Guhl, sh. 336 ve Göktürk, sh. 591 e de bk.

11) Bk. Chaubert, sh. 33-34; Paul Buchli, sh. 13-14. 
otelci ile yolcu arasında bir mukavele mevcut olmadiğı veya mevcut mu. kavele muteber bulunmadığ halde de bahis mevzuu olur.

bb) Diğer bazı müelliflere nazaran ${ }^{17}$, otelcinin mes'uliyetinin mesnedini, vedia akdinin bir nev'i olan "otelciye tevdi mukavelesi" (dépôt d'hôtellerie) teşkil eder. Nitekim BK. md. 478 in matlabı Isviçre BK. md. 487 nin fransızca metninden tercüme edilmiş olan "otelciye tevdi" ibaresini muhievidir ${ }^{13}$; otelcinin mes'uliyeti hakkındaki hükümler de vedia akdine ıüteallik babta yer almışlardır.

Bu görüşe karşı da, vedia akdinin müstevdaa, mudi tarafından verilen şeyi kabul ve onu emin bir mahalde hifzetme borcunu tahmil ettiği. halbuki yoīcunum otele getirdiği eşyayı umumiyetle kendi fiili tasarrufunda buulndurduğu dermeyan edilmektedir ${ }^{14}$. Böylece kaideten, otele getirilen şeylerin tevdiinden bahsolunamyacağ cihetle, bunlann bir nevi vedia ałdine mevzu olduklann iddia etmek hakikatten uzaklaşmağı icap ettirir. Gerçi bu tenkit nazara alınarak burada hususi mahiyette bir vedia akdinin mevcudiyeti ileri sürülmektedir ${ }^{15}$; fakat umumi vedia mefhumunun unsurlarını taşımayan bir hali, hususi bir vedia nev'i olarak tavsif sadece bir faraziyeden ibaret kalir. Otelcinin mes'uliyetine, müs. tevdanınkine müteallik kaideler tatbik edilemeyeceğinden, böyle bir faraziyeye müracaat etmekte pratik bir fayda da melhuz değildir. BK. muzda otelcinin mes'uliyetinin vedia bahsinde tanzim edilmiş olması, belki kanun vazının bu hususta Fransız MK. nun tertip tarzından mülhem ol. masıyla ${ }^{16}$ ve kıymetli eşy^y hakikaten otelciye tevdi mecburiyetini koymastyla (BK. md. 479) izah edilebilir. Binaenaleyh, otelcinin mes'uliyetini bir nevi vedia mukavelesinden istihraç etmek de tatminkâr bir hal tarzı olarak görünmemektedir.

12 Bk. Chaubert tarafindan, sh. 35 de zikredilen mủellifler; Virgile Rossel de, Manuel'inin birinci tab'inda (sh. 518) bu fikirde iken ikinci tab'inda (sh. 558) Chaubert'in tenkidlerini nazara alarak ondan vazgeçmiştir.

13 Isviçre BK. md. 487 nin matlabının fransızca metri sö̈yledir: D. Dépôt d'hôtellerie. I. Responsabilité des hôteliers...; buna mukabil almanca metỉn " $D$. Gast und Stallwirte. I. Haftung der Gastwirte..." ibaresini muhtevidir. Müşahede olunduğu üzere almanca metinde sadece otelciler ve umumi ahır işleten. lerden bahsedilip onlara "tevdi" kelimesi kullanilmamıștır.

14) Chaubert, sh. 35; Paul-Buchli, sh. 14; Oser-Schönenberger, Art. 487: Nr. 3. Bittabi. BK. ma. 479 un otelciye emanet edilmesini şart kıldığı kıymetji eşya müstesnađir.

15) Bk. Becker, Art 487, Nr, 1-2.

16) Fransız MK. otelcilerin mes'uliyetini, zarurî tevdi bahsinde tanzim etmiştir (md. 1952). 
cc) Başka bir nazariye mucibince ${ }^{17}$, otelcinin mes'uliyeti vediadar gayn bir akde, bir muhafaza mukavelesine (contrat de garde) müsteniddir; bu mukaveleye binaen, otelci yolcunun eşyasın gözetmeyi ve bu eşyanın hasarı, telefi ve sirkati dolayısıyla yolcunun uğrayacağı zarann tazminini taahhüt eder; otelci kusuru olmasa bile tazminat vermeği taahhüt ettiğinden, mukavele, bir nevi garanti mukavelesi vashın haizdir18. Becker'e nazaran ${ }^{19}$, bahis mevzuu mukavele, bir otelcilik mukavelesinin fer"i mahiyetinde olabileceği gibi, otelcilik mukavelesi in'ikad etmediği takdirde $^{20}$ müstakil olarak da vücut bulabilir. Otelcinin ağır mes'uliyetinin icabında taraflarm anlaşmasıyla bertaraf edilebilmesi de, bu mes'uliye. tin mesnedinin akdì olduğunun bir delilidir.

Eğer muhafaza mukavelesi sarahaten akdedilirse mesele yoktur. Fakat umumiyetle bu mukavelenin yolcunun otele inmesiyle zımnen aktedildiği kabul olunmaktadır. Halbuki, otelci yolcunun bavulunda ne getirdiğini bilmez ve yolcu da bu hususta bir beyanda bulunmaz; otelcinin nelerden ibaret olduğunu bilmediği eşyay zımnen muhafaza taahhüdünde bulunduğunu kabul etmek onun jradesini aşan bir tefsir tarzı olur ${ }^{21}$. Kaldı ki BK. md. 480 cümle 2 ye tevfikan, otelci mes'uliyet deruhte etmediğini yapıșturdığı ilânlarda bildirse bile mes'uliyetten kurtulamaz; eğer, otelcinin mes'uliyeti onun iradesine müstenid olsayd, onun mes'uliyeti üzerine almadığı hususundaki beyanının hüküm ifade etmesi lâzım gelirdi22.

dd) Bir takım müellifler de ${ }^{23}$, mes'uliyetin, otelci ile yolcu arasındakj muhtelif mukaveleler, ister hususî tipte tek bir akit, isterse mürekkẹ bir akit addolunsun, bunlara kanunen izafe edilen fer'i bir netice olduğu fikrini müdafaa etmișlerdir. Başka bir deyimle, bu müelliflere nazaran, otelcinin mes'uliyeti, onunla yolcu arasındaki mukavelelerin veya mukavelenin "naturalia negotii" vasfını taşıyan hükü̈mlerindendir.

17) Bk. Chaubert tarafindan sh. 36 da zikredilen müellifler.

13) Staudinger-Nipperdey, Vorbem. 8 vor $\$ 701$ de zikredijen bazı müellifler de otelcinin mes'uliyetini tek taraflı bir garanti taahhüdüne istinad ettirmektedirler.

19) Art. 487, Nr. 2.

20) Meselâ, eşya otel müstahdemini tarafından istasyondan alınmış, fa. kat sonradan taraflar oda fiatı ŭzerinde anjaşamamışlardır; eğer eşya otele nakledilirken çalınmışsa gene otelcinin mes'uliyeti ortaya çıar.

21) Chaubert, sh. 37.

22) Chaubert, sh. 37.

23) Chaubert, tarafından sh. 38 de zikredilen müellifler. 
Bu nazariye ilk bakışta cazip görünmekle beraber, otelcj ile yolcu: arasinda bir mukavele in'ikad etmediği veya mukavelenin muteber olmadiğı hallerde otelcinin mes'ul tutulmasım izah edememektedir ${ }^{24}$.

b) Halen doktrinde hâkim olan telâkkiye göre ${ }^{25}$, otelcinin mes'ú. liveti, doğrudan doğruya ve münhasıran kanundan (ex lege) neş'et eder. Kanunun bu mes'uliyet için şart kıldığı vakıalann mevcudiyeti, otelci ile: yolcu arasında muteber bir akit bulunsun veya bulunmasin, mes'uliyetin; doğması için kâfidir. Bittabii ekseriya otelci jle yoku arasında muteber bir akdî münasebet de mevcut olur; fakat böyle bir münasebetin bulun. ması zaruri değildir. Mes'uliyetin kanumi mahiyeti tanınınca, arttk lüzumsuz faraziyelere başurmağa hacet kalmaz.

Burada bir noktay tasrih etmek gerekir; o da şudur : otelcinin mesuliyeti kanuni mahiyet taşımakla beraber haksız fiilden mütevellit bir mes'uliyet değildir ${ }^{26}$; zira yolcunun uğradığı zarara otelcinin veya müstahdeminin bir haksız fiilinin sebebiyet vermesi şart değildir; mes'ul:yet, yolcunun kabul edilmesi ve onun eşyasın ofelcinin hâkimiyet sa-. hasına getirmesi vakıalannm bir neticesidir; bu vakıalarda ise bir haksız: fiil vash bulunmaz; bunlar olsa olsa birer fiili muamele (Realakte) yahut başka bir tâbirle maddî fiil olarak tevsif edilebilirler ${ }^{27}$. Mes'uliyetin haksız fiilden mütevellit olmamasının en mühim pratik neticesi, yolcunut: tazminat davasının, müruruzaman bakınundan BK. md. 60 a değil md. 125 e tâbi olmasıdır; yani bu dava hakkmda bír senelik kısa müruruzamar: bahis mevzuu olamaysp on senelik umumì mürunuzaman cereyan eder ${ }^{28}$.

\section{II - Mes'uliyetin Sartbart}

BK. md. 478 e tevfikan otelcinin ağır mes'ulìyefi şu şartlann tahak-kukuna bağlıdır :

24) Chaubert, sh. 38.

25) Oser-Schönenberger, Art. 487, Nr. 3; Paul Buchli, sh. 15; Chaubert sh. 38-39; Staudinger-Nipperdey, Vorbem. 8 vor 701; Enneccerus-Lelmann, Lehrbuch des Bürgerlichen Rechts, II. Bd., 12. Bearbeitung, Marburg 1932, sh. 594; Autenrieth-Gander, FJS, no, 661, sh. 1; Macdonald, sh. 13-14.

26) Oser-Schönenberger, Art. 487, Nr. 4; Chaubert, sh. 39-40; EnneccerusLehmann, sh. 594.

27) Staudinger-Nipperdey, Vorbem. 8 vor 701 .

28) Pétermann (sh. 15) bu hal tarzınin tatminkår olmadiồ fikrindedir;, ona nazaran otelcinin mes'uliyeti de diğer illiyete mustenid mes'uliyet hallerine, ezcümle bina sahibinin mes'uliyetine kiyasem bir senelik müruruzamana tábi olmalıăr. 
1. Otelci tarafindan yolcunun kabulï.

a) Otelci, başkalannı misafir etmek için umuma açık bir yer işlet. meği meslek ittihaz edinmiş olan şahıstır ${ }^{29}$. BK. muz otel ve han methumlan arasında bir tefrik yapmamaktadir; kasabalardaki hanlar ote!lere nisbetle daha mütevazi ve iptidai olmakla beraber, hancilar da BK. md. 478 e tâbidirler ${ }^{30}$.

Otelci hakiki veya hükmî bir şahıs olabilir ${ }^{31}$. BK. md. 478 deki mes'uliyet, otel kimin nam ve hesabına işletiliyorsa onun hakkında bahis mevzuu olur ${ }^{32}$; binaenaleyh, bir otel işletmesi hasılat icanna verilmişse, mes'ul nucir olmayıp müstecirdir; otel, malik nam ve hesabına bir vekil veya müdür marifetiyle idare ediliyorsa mes'uliyet malike terettüp eder.

Borçlar hukukundaki otelci mefhumu, otel açmak için idare hukuku mucibince konulmuş olan kayıtlara bağlı değildir ${ }^{33}$. Bu itibärla, idarî makamlar tarafından izin verilmeden açılmıs olan bir müessese cie medeni hukuk bakımından otel sayılabilir. Buna mukabil, idare hukuku cephcsinden müessesenin bir otel vasfını taşıması kaideten hususî hukukda da ayni tavsifin yapilmasin icap ettinir.

Bir mahallin otel addolunabilmesi için, onun umuma açk olmasi şartır. Bu şart, BK. md. 478 de zikredilmemiş olmakla beraber, müellif?er tarafindan ittifakla tanınmaktadı ${ }^{34}$; bunu TK. md. 12 bent 6 dan da ${ }^{3 \cdot 3}$ istihraç etmek mümkündür. Otelin umuma açı olması, herkesin veya hiç olmazsa muayyen bir sınıf halkın, otelcınnin talep ettiği ücret mukabıfinde bu müesseseden istifade edebilmesi demektir. Otelin yalnız kadın. lara veya yalnız erkeklere mahsus olması, onun umumi mahal karakterini ortadan kaldırmaz. Bir müessesenin ancak muayyen şartları haiz yol. culan kabul etmesi de, eğer bu șartlan yerine getiren her şahıs fark gözetilmeksizin misafir ediliyorsa, müessesenin umuma açı sayılmasına ve

29) Otelçinin muhtelif tarifleri için bk. : Chaubert, sh. 45; Paul Buchli, sn. 17; Pétermann sh. 3; Oser-Schönenberger, Art. 487, Nr. 9; Becker, Art. 487, Nr. 6.

30) Chaubert, sh. 52; Paul Buchli, sh. 17.

31) Teferruat için bk. Chaubert, sh. 46; Pétermann, sh. 3.

32) Chaubert, sh. 46-47; Paul Buchli, sh. 19-20; Pêtermann, sh. 3.

33) Paul Buchli, sh. 16; Chaubert, sh. 43-45; Becker, Art. 487, Nr. 6.

34) Paul Buchli, sh. 17-18; Chaubert, sh. 47-51; Oser-Schönenberger, Art. 487, Nr. 9; Becker, Art. 487, Nr. 6.

35) Mezkûr hükümde şu ibare mevcuttur : "... otel ve han.. gibi umumi mahaller..." 
otel olarak tavsifine mani değildir. Otelin umuma açı olması başka, otelcinin şartlanm yerine getiren her yolcuyu kabule mecbur olup olmadiğ meselesi yine başkadır ${ }^{36}$. Kaideten otelci istemediği şahıslan oteline almamakta serbesttir; otekinin reddine, ancak fiilî veya hukuki bir inhisamn mevcudiyeti halinde, müşahhas vakıanın diğer icaplan da gözönünde łutularak, hakkm suiistimali mahiyeti izafe edilebilir. Aile pansiyonlan umuma açı olmadıklan için kaideten bunlan işletenler yahut evlerinde bir veya bir kaç odayı kiralayanlar otelcinjn mes'uliyetine tâbi değgildirler ${ }^{37}$. Maamafih bazan aile pansiyonu ismini taşıan bir müessese de gerçekte umuma açı bir otelden başka bir şey ołmayabilir. Tefrik, müessesenin isminden ziyade, oraya kabul edilen sahislarm herbiniyle ikamet sartlan ve müddeti hakkında hususî anlaşmalar yapılıp yapılmadı̆̆, şahsî ve içtimaî vasıflan üzerinde durulup durulmadı̆̆ı, kabul için tavsiye aranı aranmadığ madığı nazara almarak yapılmalıdır,

Bir kimsenin otelci sayılabilmesi için, onun bu işi meslek ittihaz etmesi gerekiris. Başka bir deyimle, müessese tịcari bir şekiḷte işletilimeli ve bu işletme anzî değil devamlı olmalıdır. Binaenaleyh, muhtaçlara bir melce temin etmek maksadıyla kurulmuş olan hayr müesseseleri, onlann haysiyetini korumak için cüz'i bir. ücret alsalar daki otel saylmazlar ${ }^{\$ 9}$, bununla beraber, mezkûr müesseseler ticarî bir şekilde organize edilmişlerse, BK. md. 478 ve müt. onlar hakkmda da cari olur. Geçici olarak evlerinde bir veya bir kaç odayn kiralayanlar da, yukanda işaret ettiŏimiz veçhile, otelci sifatım iktisap etmezler. Bir müessesenin önüne konulan levhalarda, mektup kağıtlannda ve faturalannda kendisini otel olarak tam nıtması, müşteri celbi için prospektüsler göndermesi, reklâm yapması, üniformalı müstahdemlerinin bulunması onun tican̂ şekilde işletildiğine emare teşkil eder. Işletmenin arızi olmaması, aralısıı olması mânasına gelmez; yalnız muayyen mevsimlerde veya panayır, bayram gibi muay. yen vesilelerle çalışan oteller de mevcuttur.

Oteicilik methumuntun "başkalarını misafir etmek" unsuru "yolcu kabul etmek" le ayni şeydir. Şu halde şimdi, yolcư kabul etme mefhumu üzetinde duralım.

36) Chaubert, sh. 48 .

37) Teferruat için bk. Chaubert, sh. 58-60; Becker, Art. 487, Nr. 7.

38) Oser-Schönenberger, Art. 487, Nr. 10; Paul Buchli, sh. 18-19; Chaubert, sh. 51-52; Autenrieth-Gander, sh. 1; Pétermann, sh. 4.

39) Chaubert, sh. 57-58; Pétermann, sh: 4. 
b) Yolcu kabul etmeden maksat, hariçten gelen şahısların otelde: kendilerine tahsis edilen yerde misafir edilmesidir (héberger, Beherbergung) ${ }^{40}$. Misafir etmeden, bilhassa bu şahıslann oturmasının ve yatmasmın temini anlaşılmalıdr; bittabii bunlara yemek ve içki verilmesi, giyeceklerin temizlenmesi gibi çeşitli başka edalar da eklenebilir. Fakat sır' yemek, içmek veya otelde bulunanlardan biriyle görüuşmek için otele gelen şahıslar BK. md. $\mathbf{4 7 8}$ den istifade edemeyecekleri gibi kahve ve lokanta işletenler de otelcinin mes'uliyetine tâbi değildirler ${ }^{41}$. Zaten umumiyetle bu sonuncu yerlere, otele olduğu gibi fazla esya ile gidimez; ves. tiyere burakılan essya hakkunda ise vedia akdi bahis mevzuu olur.

Otelde misafir edilen şahsın geceyi orada geçirmesi zarureti yoktur42; o, herhangi bir sebepten bütün gece dışanda kalmuş olabilir; yahut yol. culuk esnasinda dinlenmek ve temizlenmek maksadıyla sadece gündüz: bir kaç saat için oda tutanlar da vardır.

Yolcuya muhakkak hususî bir oda tahsis edilmesi gerekmez ${ }^{43}$; onun. başkalanyla birlikte yahut müşteri tehacümü dolaysile holde veya banyo odasinda yatnlması da kabildir.

Yolcu kabulü kaideten bir ücret mukabilinde olur. Otelci bir dos. tunu yahut akrabasın yahut iyilik maksadyla muhtaç bir kimseyi ote-linde bedava yatırmıssa, onlara karşı BK. md. 478 e tevfikan mes'ul or. maz; filhakika bu gibi hallerde meslekî faaliyetin icrasından bahsedile$\mathrm{mez}^{44}$. Buna mukabil bir kimseyi misatir etmenin, bedava olmasına rağmen, meslekì faaliyet çerçevesine girdiği haller de mevcuttur ${ }^{45}$; ezcūm. le otelci bir seyahat acentasmı yahut yolculara rehberlik eden şahsı veya: grup halinde seyahat edenlerin reisini ücretsiz olarak' ağırlarsa vaziyet* böyledir.

Otelcinin müstahdemini de eşyalanıın hasara uğraması takdirinde.

40) Paul Buchli, sh. 19; Chaubert, sh. 52-53; Pètermarn, sh. 7.

41) Chaubert, sh. 61-64; Paul Buchli, sh. 19; Oser-Schönenberger, Art. 487, Nr. 9-10; Becker, Art. 487, Nr. 4; Pétermann, sh. 5 ve 8.

42) Oser-Schönenberger, Art. 487, Nr. 10; Chaubert, sh. 79-81; Pêter-. mann, sh. 7 .

43) Oser-Schönenberger, Art. 487, Nr. 10.

44) Oser-Schönenberger, Art. 487, Nr. 10; Chaubert, sh. 78-79; Paul: Buchli, sh. 24; Pétermann, sh. 7.

45) Federal Mahkeme, RO 33 II 263, "Spelterini c. Seiler"; Chaubert, sh.. 78; Paul Buchli, sh. 24; Pétermann, sh. 8. 
BK. md. $478 \mathrm{i}$ ileri süremezler; çünkü onlar yolcu sıfatını haiz değildirler ${ }^{46}$.

Otele el koyan askerî makamlann da mezkûr hükümden faydalanmasi mümkün değildir ${ }^{4}$.

- Yolcunun otelci ile bir anlaşma olmaksızın odasın devrettiği veya paylaştığı üçüncü şahıs otelcinin ağır mes'uliyetini dermeyan edemez ${ }^{48}$.

Otelde mallannı satmak, teşhir etmek veya büro yahut muayenehane olarak kullanmak maksadıyla bix oda veya bir defile için bir salon kiralayan kimse de yolcu vashinı taşmaz ${ }^{49}$.

Yolcudan muhakkak seyahata çkmış ve kısa bir müddet için otele inmiş şahıs anlaşımamahdır. Otelin bulunduğu şehirde ikamet edip de herhangi bir sebepten otelde kalan kimseler de BK. md. 478 den istifade ederler ${ }^{50}$. Bazl müellifler ${ }^{51}$, bu gibi kimselerin oteli ve otelciyi tanıma: lan, binnetice otelde oturmanın risklerine katlanmalan gerektiği fikrindedirler. Haßbuki büyük şehirlerde böyle bir tanıma imkânı olmadığı gibi otelcinin kendisi tanınsa bile otele girip çkanlan kolayllkla tesbit mümkün değildir; otelcinin mes'uliyeti zamanumuzda artık onun şüpheli bir şahıs olduğu mülâhazasına dayanmamaktadrr.

Otelde uzun müddet kalmak da BK. md. 478 hükmünü ileri sürmeğe mani teskil etmemelidir; filhakika sayfiye otellerinde bütün bir mevsimin geçirildiği vakidir. Blazı müellifler ${ }^{52}$, muayyen bir konfordan istifade maksadryla devaml surette otelde yerleșen şahıslara yolcu denemeyeceğini beyan etmektedirler. Kanaatimizce, bu sahılar sadece bir kiracı vaziyetinde olmadıkça $B K$. md. 478 e istinad edebilmelidirler; zira oteldeki daimî şahıs değişikliğinden doğan tehlike onlar için de mevcuttur ${ }^{53}$. Fakat onlarn otel içinde müstakil bir daire tutmalan, kendi esyalann getirmeleri, kendi hizmetkârlannı kullanmalan gibi otel işlet.

46) Paul Buchli; sh. 23; Chaubert, sh. 77-78; Oser-Schönenberger, Art. 487, Nr. 10; Petermann, sh. 8.

47) Petemann, sh. 8.

48) Chaubert, sh. 81; Pétermann, sh. 8.

49) Paul Buchli, sh. 24; Chaubert, sh. 83-84; Becker, Art. 487, Nr. 4; Pestermann, sh. 8.

50) Paul Buchli, sh. 25; Chaubert, sh. 85-86; Becker, Art, 487, Nr. 5; Pétermann, sh. 8.

51) Ezciumle Rossel, sh. 559.

s2) Chaubert, sh. 87-90; Pétermann, sh. 8.

53) Ayni fikirde Becker, Art. 487, Nr. 4; Paul Buchli, sh. 24. 
mesinden faydalanmadıklarını gösteren emareler varsa artık otelci BK. md. 478 e binaen mes'ul kılınmamalıdır.

Yolcu sıfatını ileri süren kimse bunu isbatla mükelleftir; bunun için otelde oturduğu hakkında hâkime kanaat vermesi kâfidir; buna mukabil otelci de meselâ onu, dostu olduğu için bedava misafir ettiğini iddia ve isbat edebilir'54.

BK. md. 478 deki davayı açmak hakkı, getirdiği eşyanın maliki olmasa bile ${ }^{5}{ }_{5}$ münhasıran yolcuya aittir ${ }^{56}$; yolcu malik tarafından mes'ul kılınamasa dahi ${ }^{57}$ yine otelciye karşı tazminat talebinde bulunabilir; diğer taraftan, yolcunun tazminat talebini malike temlik etmesi de müm kündür.

Baż müesseseleri işletenlerin, yolcu m:safir etme gayesini taşımamalarna veya böyle bir gayeyi tâli olarak takip etmelerine rağmen, otelcinin mes'uliyetine tabi tutulup tutulamayacağı münakaşalıdır:

Hususî klinikler ve sanatoryomlar kaideten otel sayllamazlar ${ }^{58}$; çünkü bunlarda yolcu ağırlamaktan ziyade tedavi maksadı galiptir. Bununla beraber, hasta olmayanlan da kabul eden ve dahili nizamı bir tedavi yerinin sartların arzetmeyen klinik ve sanatoryomlar hakkında halin icaplarına göre bir otel muamelesi yapmak kabildir.

Yatılı tahsil ve terbiye müesseseleri de yolcu kabulünden gayn gayelere hizmet ettiklerinden otellere kuyaslanamazlar ${ }^{59}$.

Yolcu misafir etmeden başka maksatların mevcudiyeti genel evleri işletenlerin de otelci gibi mes'ul sayılmalanna engel olur ${ }^{60}$. Kald $\mathbf{k i}$ bu gibi şahıslara karşı BK. md: 478 e binaen açılan bir davanın ahlâkı mugayir bir münasebete istinad edildiği için reddolunması kuvvetle muh. temeldir; bahis mevzuu mahallerde eşyası hasara úğayan veya çalman şahıs ancak haksız fiillere müteallik hükümlere tevfikan tazminat isteyebilir.

54) Chaubert, sh. 90-91.

55) Meselâ, otele inen seyyar bir tüccar memurunun satmak için yanında taşıdı.̆ mülkiyeti patronuna ait eşya çalınmıştır.

56) Chaubert, sh. 91-93; Becker, Art. 487, $\mathrm{Nr}$. 4; Oser-Schönenberger. Art. $487, \mathrm{Nr}, 35$.

5т) Meselâ, eșya onun kusuru olmaksızın yanmıştır.

58) Bk. Chaubert, sh. 49-50, 65; Becker, Art. 487, Nr 9; Pétermann, sh. 5.

59) Chaubert, sh. 69; Becker, Art. 487, Nr. 9; Pétermann, sh. 4.

60) Chaubert, sh. 69-70. 
U'mumi plâj ve deniz hamamı işletenler de yolcu ağırlamadıklanı için BK. md. 478 mucibince mes'ul olmazlar ${ }^{61}$. Bununla beraber, bazt müellifler ${ }^{62}$, bir otel işletmesine bağlı tehlikelerin benzerleri bu çeşit müesseselerde de mevcut olduğu cihetle mezkû́r hükmün kıyasen veya hiç olmazsa de lege ferenda onlara da teşmiline taraftardirlar.

Yataklı vagonlann ve yolcu vapurlarmin da otellerle müşabehet arzeden taraflan mevcuttur. Şu kadar ki bunlarda nakliye maksadı yolcu misafir etme maksadının yanında ağır basmaktadır; bu itibarla bun. lan işletenler hakkında otelcilerin mes'uliyeti hakkındaki hükümlerin tatbik edilmemesi63 münasip olur ${ }^{64}$. Bir kısım müellifler ${ }^{95}$ ise yatakl vagonlarn ve yolcu vapurlarının bir nevi tekerlekli veya yüzen otel ol. duklann ve otel işletmesine has riskler:n bunlarda da bulunduğunu beyanla aksi fikri müdafaa etmektedirler.

2. Yolcỵun eşyasm getirmesi.

Otelcinin hususi mes'uliyetinin doğması için yolcunun eşyasım onun hâkimiyet sahașna (Herrschaftsbereich) getirmesi şarttır ${ }^{66}$.

a) Yolcunun eşyasınłan onun otele getirdiği bütün menkuller an. laşılmalıdır ${ }^{67}$. Kanunda mes'uliyetîn doğumu bakımından, kaideten eşyanın mahiyetine göre bir tefrik yapılmamaktadır. Yalnız kıymetli eşa, mühim miktarda para ve kıymetli evrak hakkında hususi bir hüküm mevcuttur; bu hüküm üzerinde daha ileride duracağı̆ ${ }^{68}$. Diğer taraftan, yine ileride göreceğimiz veçhile ${ }^{69}$, yolcunun getirdiği otomobil, araba

61) Chaubert, sh. 66-68; Pètermann, sh. 4; Becker, Art. 487, Nr. 9; OserSchönenberger, Art. 487, Nr. 9; Rossel, sh. 559. Alman hukuku için bk. : Staudinger-Nipperdey, 701, Nr. 8; Enneccerus-Lehmann, sh. 595.

62). Paul Buchli, sh. 20-21; Chaubert, sh. 67. Zürich Kantonunda Meilen Hukuk Mahkemesinin Paul Buchli, sh. 21 de zikredilen kararn.

63) Bittabii bu mes'uliyet yolcunun bagaja vermediği ve yanındå göturr. düğì eşya için bahis mevzuu olur.

64) Becker, Art. 487, Nr. 8 ve 9; Chaubert, sh. 73-76; Pétermann, sh. 4; Rossel, sh. 559; Stauđinger-Nipperdey, 701, Nr. 9; Enneccerus-Lehmann. sh. 595 .

65) Paul Buchli, sh. 22-23; Oser-Schönenberger, Art. 487, Nr. 9.

86) Oser-Schönenberger, Art. 487, Nr. 12; Paul-Buchli, sh. 32; Becker, Art. $487, \mathrm{Nr} .13$ ve 17 .

67) Oser-Schönenberger, Art. 487, Nr, 11; Becker, Art. 487, Nr. 12; Paul Buchli, sh. 25; Chaubert, sh. 113-116; Pêtermann, sh. 9.

68) Bk. aşağıda IV, 2.

69) $B k$. aşağıda $V$. 
gibi vasıtalann ve binek veya koşum hayvanlarmin zarara uğraması veya . çalınması yüzünden otelcinin BK. md. 478 mucibince mes'ul olup olmayacağı münakaşalıdır.

b) Yolcunun eşyasının otelcinin hâkimiyet sahasma girip girme . diğinin nasıl tesbit olunacağı hususunda BK. muzda bir sarahat yoktur. $\mathrm{Bu}$, daha ziyade, her müşahhas vakıanın icaplarina, mahalli örfe ve muamelâtta cari telâkkiye göre tayin olunur ${ }^{70}$.

Bazı müellifler ${ }^{71}$, eşyanm getirilmesi mefhumunu tarif etmek için, Alman MK. § $701 \mathrm{f}$. II den mülhem olmuşlardır. Mezkûr hükme tevfikan, "yolcunun, otelciye yahut onun esyayı kabul için tayin ettiği veya halin icaplanna nazaran bu husus için tayin edilmiş görünen adamlanna teslim eylediği, veya onlar tarafindan gösterilen mahalle, yahut böyle bir mahal gösteilmemişse bu hususa tahsis edilmiş olan mahalle brraktıǵt eşya getirilmiş (eingebracht) sayslu". Müşahede olunduğu üzere, otelciye veya onun salâhiyetli müstahdemlerine verilmeyen veya oblarn gösterdiği yere burakılmayan eşya, ancak bu işe tahsis edilmiş mahalle. konulduğ takdirde, otelci onun hasarnndan veya sirkatinden mes'ul olur. Eşyanın konulmasına mahsus mahallin neresi olduğunu yine müşahhas vakıanın icaplanna, mahallì örfe ve muamelâtta carì telâkkiye göre tayin etmek icap eder.

Alman MK. nun sistemi kabul edilince, yolcu, eşyanin konulduğı: yerin buna tahsis edilmiş bulunduğunu isbatla mükellef olur. Halbuk: Fransız hukukunu örnek alan diğer bazı müelliflere göre ${ }^{72}$, yolcunun eșyasını otele getirdiğ̣nì isbat etmesi kâfidir; otelci ise, yolcunun eşyasın: otel dahilinde bu işe mahsus olmayan bir mahałle koyduğunu, binaenaleyh onun kendi kusuru bulunduğunu isbatla mes'uliyetten kurtulabilir ${ }^{73}$. Bu

70) Paul Buchli, sh. 32; Oser-Schönenberger, Art. 487, $\mathrm{Nr} .14$.

71) Ernst, sh, 54 ve müt.; Becker, Art. 487, Nr. 13.

72) Chaubert, sh. 118-119, 121; Paul Buchli, sh. 32-33.

73) Chaubert (sh. 118 ve müt., 122 ve müt.) bizzat otel ile onun musştemilâtı (dépenđances) arasında da bir tefrik yapmaktadır. Bu mủellife nazarai, eğer eşya doğrudan doğruya yolcunun misafir edilmesine yaramayan, fakat do. layısıyla otelin işletilmesine hizmet eden mutfak, mahzen, avlu, kömürlük, bitiş̧ik lokanta, garaj gibi mahallerde, yani otelin müştemilâtında hasara uğrạ veya çalınırsa, otelci Bk: md. 478 mucibince mes'ul edilememelidir, meğer $k i$ eșyanın buralara konulmasına muvafakat etmiş olsun. Paul Buchli'nin (sh. 33) haklı olarak beyan ettiği veçhile, böyle bir tefrik lừzumsuzdur; zira müştemilât mefhumu vazıh değildir; bundan başka, halin icaplạnna göre eşyanın otelin müștemilâtında bırakılması yolcunun kendi kusuru sayılmak suretile ote cinin mes'uliyetten beri krlınması otelciyi himaye için kảfidir. 
ssonuncu sistem bize de daha mülâyim gelmektedir; filhakika BK. muzda, esyanın otel dahilinde kendisine tahsis edilmiş bir yere konulması zarureti tasrih edilmemiștir.

Ȩ̇anun konulmasına mahsus mahal muhakkak yolcuya aynlan soda değildir 4, halin icaplarna göre otelci, otel holünde, koridorlannda, bürosundan, salonlarinda, banyo ve helâlannda, yolculan istasyonlardan ggetiren otele ait otobüste kaybolan eşyadan da' mes'ul olur. Eğer otelci yer darlığ dolayısile müşterileri için üçüncü şahıslar nezdinde odalar tutmuşsa anun mes'uliyeti bu odalarda husule gelen zarara da teşmil edilmek gerekiri ${ }^{75}$.

Stiffler ${ }^{76}$, yolcunun bizzat üstünde taşıdığı eşya hakkında otelcinin hususî mes'uliyetinin bahis mevzuu olamayacağ fikrindedir. Diğer muiellifler ${ }^{77}$ hakl olarak bu fikre iştirak etmemektedirler; yolcu otel dahilinde bulunduğu müddetçe, bizzat üzerinde taşıdığı eşya için dahi BK. md. 478 hükmümden istifade edebilmelidir; çünkü otel işletmesine bağlt risklet onun eşyasmı üzerinde taşıması veya odasınm bir yerinde burakmasiyle de-

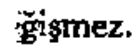

Eğer eşya oteleiye veya onun salâhiyetli müstahdemlerine teslim edi]mis veya onlann gösterdiği yere konulmuş olursa, artık esyanın durdư̆u yerin ba işe mahsus olup olmadiğını araştırmağa hacet kalmaz. Müstahdemin görünüüste salâhiyetli olmast kâfidir ${ }^{78}$; ezcümle otel müdürü veya kâtíbi, kapıcı, oda hizmetçileri, asansörcü, otel otobüsünün soförü eşyayı teslim almağa salâhiyetli saylabilirler; buna mukabil kaideten ahçı, bahçıan veya kaloriferci bu hususła salâhiyetli değildirler. Yolcunun ykanmak için otel müstahdemlerine verdiği çamaşṛlar otelin çanaşırhanesin. de yikanyorsa bunlar hakkında BK. md. 478 tałbik edilir; çamaşırlar bir üçüncü şahsa aìt çamaşırhanede ylkatılıyorsa otelci sadece bu çamaşırha. nenin intihabmdaki kusurundan mes'uldür ${ }^{79}$.

Esyanın nereye konulacağinın her yolcuya ayn ayn gösterilmesi icap

74) Oser-Schönenberger, Art. 487, Nr. 14; Paul Buchli, sh. 33.

75) Patil Buchti, sh. 33; Becker, Art. 487, Nr. 16.

76) Das Receptum Cauponum und die Haftplicht der Gastwirte ex recepto, Diss. Chrur 1903, sh. 54.

77.) Paul BuchJi, sh. 34; Becker, Art. 487, Nr. 17.

78) Teferrưat içiv bk. Chaubert, sh. 135-137; Oser-Schönenberger, Arr. 487, Nr. 13; Becker, Art. 487, Nr. 14.

79) Becker, Art. 487, Nr. 17. 
etmez; bu hususta kolayhkla görünebilecek yerlere ilănlar asılmıșæa eşyanın bırakılacağ mahallin gösterilmiş olduğunu kabul etmek lâzım gelin ${ }^{80}$.

c) Eşyanın hangi andan itibaren getirilmiş ve hangi andan itibaren götürülmüş addolunacağı, başka bir deyimle, otelcinin hususî mes'uliye. tinin başlama ve sona erme anlannın hangileri olduğu doktrinde ihtilấflıdrr.

Bahis mevzuu mes'uliyete akdî mahiyet izafe edenler için meselenin. halli basittir: mes'uliyet, otelci ile yolcu arasındaki mukavelenin in'ikad, anında başlar ve mukavelenin ortadan kalkmasiyle sona erer. $\mathrm{Bu}$ görüş tarzı daha evvel de kaydettiğimiz gibi tatminkâr değildir; zira otelcinin nes'uliyeti, sonradan taraflar anlaşamasa ve bir mukavele vücut bulmasia dahi yine ortaya çıkabilir; meselâ yolcu bavullannı otelin istasyondaki şoförüne teslim etmiş ve yolda bunlardan bir kısmı çahnmış ise, otele gelince taraflar fiat üzerinde anlaşamamış olsalar dahi otelciyi eşyanın yoldax. uğradığı hasar yüzünden BK. md. 478 mucibince mes'ul kılmak mümkürndür; keza in'ikad eden mukavele muteber olmasa dahi yine vaziyet ayn:dir.

Chaubert'e nazaran ${ }^{81}$, otelcinin mes'uliyeti yolcunun vusulü anından itibaren kendisini gösterir; vusulden yolcunun otelcinin hizmetlerinden otel içinde veya dışında istifade etmeğe başlaması anlaşılmalıdır; mes'uliyet yolcunun otelden aynlması, yani otelcinin hizmetlerinden artik istifade etmemesi anından itibaren sona erer. Chaubert ${ }^{82}$, bazi hallerde otelcinin hizmetlerinden istifade kıstasi yanında otelde fiilen ikamet sarıın da koymaktadır: yolcu kendisi vasıl olmazdan önce esyasını yollayacak. olursa bu eşya için otelci BK. md. 478 e binaen mes'ul tutulamaz; çünkiî bu hüküm yolcuyu otelde fiilen ikameti esnasında eşyasının maruz bulunduğu tehlikelere karşı himaye maksadiyla sevkolunmuştur; BK. md. 478 tatbik edilemeyince șu hal suretleri hatıra gelir: eğer yolcu otelciyle aralarında hiçbir anlaşma olmaksızın eşyasın yollamışsa otelci bu eşyayı reddedebilir; kabul ederse ya zımnî bir vedia yahut da vekâletsiz iş görme karşısında bulunulur; yolcu otelciyle anlaşıp eşyasını önceden göndermişse bizzat kendisi gelinceye kadar vaki zarar için, oteici sadece vedia akdji hüjkümleri mucibince mes'ul kulnnabilir.

Kanaatimizce Chaubert'in otelcinin hizmetlerinden istifade kıstasina inzimamen koyduğu fiilî ikamet şartı fazladır; gerçi" "vusul" ve kanunda.

so) Becker, Art. 487, Nr. 15.

81) Sh. 126-127. Ayni fikirde Pétermann, sh. 9.

82) Sh. 130-131. 
kullanılan "nazil olan yolcular" mefhumlan yolcunun otelin bulunduğtr. mahalle gelmesini tazammun eder; ancak otelcinin mes'uliyetini, önceden gönderilen eşya bakımindan yolcunun o mahalle gelmesinden cvvele tesmil etmex isabetli olur ${ }^{83}$; çünkü otelcinin hususi mes'uliyeti yolcunun şahsının değil eşyasının maruz olduğu tehlikeler dolayısile kabul edilmiştix; yolcunun kendisi henüz muvasalat etmemiş olsa bile eşyası otelcinin hâkimiyet sahasına girmis ve yolcu onun, hizmetlerinden istifadeye başlamıstrr. Hülâsa fikrimizce otelcinin mes'uliyeti, yolcunun bu sıfatla otelciniri hizmetlerinden istifadeye başladığt ve esyanın otelcinin hâkimiyet sahasłna girdiği andan ${ }^{84}$, mezkûr hizmetlerden yolcu sıfatryla istifadenin sona. erdiği veya eşyanın mezkûr hâkimiyet sahasından çıktığı ana kadar devam etmelidir. Bu müddet zarfinda yolcu yeni esya getirirse otelci onlar için de mes'ul olur. Yolcu eşyasının istasyondan otele ve otelden istasyona' otelcinin adamlan vasitasiyle nakli esnasinda uğradığı zarar için de BK. md. 478 i dermeyan edebilir ${ }^{85}$; zira o, eşyayı otelcinin adamlanna teshm etmekle otele henüz gelmemesine veya oteli terketmesine rağmen otelcinin hiżmetlerinden yolcu sifatyla istifade etmektedir.

Yolcunun odasmı muhafaza etmekte ve otel ücretini ödemskte devam ederek ótelden muvakkaten aynlması otelcinin mes'uliyetine son vermez $^{86}$. Buna mukabil, skk sik ayni otele inen kimse için bu mes'uliyet devaml değildir ${ }^{87}$; her geliş gidişte yeniden başlar' ve sona erer. Eğer bir müddet sonra uönecek olan yoicu, odasın muhafaza etmeksizin ve oteí ücret:ni ödemeksizin eşyasın saklaması için otekiye bırakmışsa ortada adí bir vedia akdinden başka bir şey yoktur ${ }^{88}$; eşya bir daha dönmeyecek olan

83) Ayni fikirde Paul Buchli, sh. 35; Oser-Schönenberger, Art. 487, Nr. 15.

84) Bittabii otelci yolcu ile aralarinda bir anlaşma bulunmaksizin onun otele kendisi gelmeden önce gönderdiği eşyayı kabul etmeyebilir.

85) Bk. Chaubert, sh. 133-139; Oser-Schönenberger, Art. 487, Nr. 15; Pétermann, sh. 9 .

86) Chaubert, sh. 141-142; Pétermann, sh. 10; Becker, Art. 487, Nr, 18; Paul Buchli, sh. 36; Zürich Yüksek Mahkemesi, BIZR, 21 (1922), sh. 99.

87) Chapubert, sh. 142:

88) "Davacının misafir kaldığı otelden alâkasını keserek giderken mezkûr otel yazrcısına o zaman teslim ve tevdi ettiği eşanın çalınmasından ötürth zarar ve żyan dava etmesine göre hâdisede BK. nun otelcilerin mes'uliyetin. den bâhis olan 478 inci maddesi hükümleri tatbik olunmayı 463 uncü ve ondat sonra gelen maddeleri hükümlerinin tatbik olunacağ 1 gözönünde tutulmayarak yazıll şekilde yargılama yapılması yolsuzdur". Temyiz Mahkemesi 4. H. D. 30/4/1945, 1164/1650, Kâmil Tepeci, Notlu ve tzahlı Borçlar Karíunu, Ankara: 1949 , sh. 613-614. 
yolcu tarafindan arkasindan yollanilmak veya bir üçüncü şahsa teslim edilmek üzere bırakılmışsa bir vekâlet akdinden bahsedilebilir ${ }^{89}$.

Yolcunun oteli terkederken orada unuttuğu eşya bakımından otelcinin hangi hükümlere tevfikan mes'ul tutulacağı da münakaşalı hususlardandır. Macdonald'a nazaran ${ }^{90}$, bu eşya için de otelcinin hususî mes'utiyeti devam eder; çünkï bu gibi eşyanın sáklanılması ve yolcuya gönderilmesi otel işletmesine giren mutad hizmetlerdendir. Buna mukabil doktrinde hâkim olan görüş mucibince ${ }^{91}$, burada BK. md. 478 tatbik edilemez; zira otelci artık risklerinin karşılığını teşkil edecek bir ücret almamaktadır; bundan başka bizzat yolcunun eşyaya nezaret imkânı tamamen ortadan kalkmışır; nihayet, eşyasını unutan yolcu eşyasını götürenden daha fazlı himayeye lâyrk değildir diyen müellifler de mevcuttur ${ }^{92}$. Bu görüş kabul edildiği takdirde, unutulan eşya daha önceden otelciye tevdi edilmişse otelci vedia hükümlerine, tevdi edilmemişse sadece haksız fiillere müteallik hükümlere binaen mes'ul olur; yolcu sonradan eşyasının gönderilmesini isterse vekâlet, otelci kendiliğinden eşyayı gönderirse vekâletsiz iş görme hakkındaki kaidelere müracaat gerekir.

Otelci BK. md. 482 ye tevtikan hapis hakkın kullanıyorsa, eşyanın hasara uğraması, telefi ve sirkati hallerinde menkul rehninde mürtehinin mes'uliyetiyle alâkalı hükümler (MK. md. 859) tatbik olunur ${ }^{93}$.

d) Otelcinin eşyanın getirildiğinden ve nelerden terekküp ettiğin. den mutlaka haberi olmasına veya sarahaten eşyanın getirilmesi için rıza göstermesine lüzum yoktur ${ }^{94}$. Şu kadar ki kıymetli eşyanın mevcudiyetini otelciye bildirmemek halin icaplanna göre yolcu için bir müterafik kusur teşkil edebilir.

Eşyanm getirilmesi hususundaki zaman ve mekâna ait bütün şartların tahakkuk ettiğini isbat külfeti yolcuya terettüp eder ${ }^{95}$. Bu hususta mutlak bir isbat aramak yolcunun haklannı tehlikeye düşürebilir; bu it:-

89) Chaubert, sh. 144.

90) Sh. 26 ve mut.

91) Paul Buchli, sh. 36-37; Becker, Art. 487, Nr. 18; Oser-Schönenberger, Art. 487, Nr. 15; Ernst, sh. 46 ve muit. ; Chaubert, sh. 144; Federal Mahkeme, RO 33 II 424, "Cladiere-Dubois c. Morand et Brauns".

92) Paul Buchli, sh. 37.

93) Chaubert, sh. 144.

94) Bk. Chaubert, sh. 127-130; Pétermann, sh. 9 .

95) Chäubert, sh. 148-149; Oser-Schönenberger, Art. 487, Nr. 16; Paul Buchli, sh. 45-46; Becker, Art. 487, Nr. 35; Pétermann, sh. 10. 
barła kuvvetli emarelerin eşyanın getirildiği hakkında hâkime kanaat bahşetmesi kâtidir. Yolcunun kaybolduğunu iddia etț̆gi eşyayı hakika, ten getirip getirmediği araştınlırken onun içtimai mevkii, seyahat maksad, ikamet müddeti gözönünde tutulmalıdır. Yolcu kendisine düşen isbat külfetini yerine getirdiği takdirde, otelci onun esyasının otel haricinde zarara uğradığını veya böyle bir eşyanı hiçbir vakit mevcut olmadı̆̆ın ispat edebilir.

3. Eşyanın hasara uğraması, telef olması veya çahnması.

Otelcinin BK. md. $47 \&$ mucibince mes'ul edilebilmesi için üçüncü sart, yolcunum getirdiŏi eşyanın hasara uğraması, telef olması veya çalinmasıdır. Şu halde, otelci yalnız eşyanın załını alâkalandıran zaran mez kûr hükme binaen tazmin etmekle mükelleftir; yoksa meselâ, yolcu, ę̧yasın bu eşyanm zatına zarar vermeksizin otelcinin haksız olarak alıkov. ması yüzünden, mamelekinde husule gelen eksilmenin tazminini BK. md. 478 e müsteniden isteyemez ${ }^{96}$; 0 , sadece mes'uliyet hakkındaki umumî hükümleri, yahut eşyay bir akit (faraza vedia) icabl otelciye teslim ei. mişse 0 akde müteallik hükümleri ileri sürebilir.

Otelde ikameti esnasında yolcunun esyası değil şahsi bir zarara uğrayacak olursa gene $\mathrm{BK}$. md. $478 \mathrm{i}$ tatbik etmek mümkün değildir ${ }^{97}$. Bu takdirde yolcu, ya otelcinin akdî veya akdi olmayan kusurunu (BK. md. 96 ve müt. yahut md. 41 ve müt.) yahut da objektif mes'uliyet sebeblerinden birini (meselâ BK. md. 58) dermeyan edebilir.

\section{III —. Mes'uliyeti Veya Dava Hakkmı Ortadan Kaldıran Haller.}

Tetkiklerimizin başında, otelcinin mes'uliyetinin kusura istinad etmeyen bir netice mes'uliyeti olduğuna işaret etmiştik. Filhakika BK. md. 478 e tevfikan, otelci kendi hakimiyet sahasına yolcu tarafindan getirilen esyanın uğradığı zaran, kaideten, hangi sebepten ileri gelirse gelsin tazminle mükelleftir. Ancak kanun vazı bu tazmin mükellefiyetini makul va hakkaniyete uygun bir şekilde sınırlandrmak lïzumunu hissetmiştir; bunun için de otelciye zarann kendi işletmesine has tehlikeler dışıııda muayyen bazı sebeplerden doğduğunu isbat suretile mes'uliyetten kurtulmak imkânını bahşetmiştir. Eğer otelci, zarann yolcuya veya onu ziyarete gelen yahut refakatinde bulunan kimseye isnadı kabil olduğunu veya mücbir sebeplerden neş'et etttiğini veya eșyann mahiyetinden mütevellid bulun-

96) Chaubert, sh. 109; Pétermann, sh. 11.

97) Oser-Schönenberger, Art. 487, Nr. 17. 
duğunu isbat ederse artık tazminatla mükellef tutulamaz. Diğer taraftan, otelcinin hususi mes'uliyetinin taraflar arasındaki bir mukavele ile de hafffletilmesi veya bertaraf edilmesi mümkündür. Nihayet yolcu zaranna vakıf olur olmaz otelciye bildirmezse BK. md. 478 ve müt. e binaen dâva açmak hakkı sukut eder. Otelcinin hususî mes'uliyetini veya ona karșı olan dâva hakkını ortadan kaldıran bu haller aşağıda ayn ayn incelenecektr.

1. Zarara yolcunun yahut onu ziyarete gelen veya refakatinde bulunan şahısların sebebjyet vermesi.

a) BK. md. 478 cümle 1 mucibince, otelci zarann yolcuya veya onı ziyarete gelen yahut refakatinde bulunan şahıslara isna: kabil olduğun isbat ederse mes'uliyetten kurtulur. IBK. nun almanca metninden, zaranr. bahsi geçen şahıslara kabili isnad olmasmın, zarara onlann sebebiyet vermesi mânasına geldiği açıkça anlaşılmaktadır ${ }^{98}$. Şu halde otelcinin mes'v. liyetten kurtulmak için mutlaka yolcunun veya onun fiillerinden mes'ul olduğu şahıslann kusurunu isbat etmesine hacet yoktur ; sadece bu şahıs. ların fiilleriyle zarar arasında bir uygun illiyet rabıtasınm bulunduğuriu belirtmesi kâfidir"9o; kusurun aranmaması bilhassa mezkûr şahıslarm tem. yiz kudretini haiz olmamalan halinde ehemmiyet arzeder.

Zararm hangi hallerde yolcunun fiilinden neş'et etmiş sayılabileceği hususunda umumi kaideler koymak mümkün değildir. Her müșahhas vakıada ikamet müddeti, otelin çeşidi ve sınıfı ${ }^{100}$, getirilen eşyanın nev'i ve tehlikelilik derecesi ${ }^{101}$ gibi hususlar, mahallî örf ve muamelâtta cari . telâkkigözönünde tutulmalıdır ${ }^{102}$. Federal Mahkeme, kür yapmak için uzun müddet kalınan bir otelde oda kapısının otel hizmetkârlarınm girebilmesi için kilitlenmemesi halinde zararnn yolçuya kabili isnat olduğunu kabul etmemiştir ${ }^{103}$; buna mukabil, yolcunun eşyasını koyduğu koridor-

98) "...dass der Schaden durch den Gast selbst oder seine Besucher, Bezleiter oder Dienstleute... verursacht worden ist."

99) 'Oser-Schönenberger, Art. 487, Nr. 22; Becker, Art. 487, Nr. 26; Paul Buchli, sh. 39; Chaubert, sh. 189.

100) Federal Mahkeme; RO 39 II 724, "A. G. Neues Stahlbad St. Moritz c. Harpner".

101) Federal Mahkeme, RO 36 II 61., "Colteletti c. Hafen".

102) Oser-Schönenberger, Art. 487, Nr. 22; Paul Buchli, sh. 39; Chaubert, sh. 186.

103) RO 39 II 724. Temyiz Mahkememizin 4. H. D. 13/11/1945 tarih ve 2451/4126 sayll kararında yolcunun kapıyı kilitlememesini ve 2000 líra parasınj cebinde bırakmasını, onun müterafık kusuru olarak saymıştır (Tepeci, sh. 614-615). 
daki bir dolabm kapağını veya odasında kıymetli eşya ihtiva eden bir mahfazayı kilitlememesi, odadan çıktığı zaman saatini veya parasını meydanda birakmast ${ }^{104}$, anahtan kapı önündeki çengele asması105 gibi fiil ve ihmallerinin, vakualann hususiyetleri hesaba katularak, otelcinin mes'uliyetter beraatı için kâfi addolunabileceğini beyan eylemiştir. Pencerenin odays havalandırmak için münasip zamanlarda açık bırakılmasından doğan tehlikeler otel işletmesine has olup yolcuya isnad edilmemelidir ${ }^{106}$. Diğer taraftan, meselâ, anahtann oda kapısının üstünde bırakılması hırsızın pencereden girdiği sabit olursa otelciyi mestuliyetten kurtarmaz ${ }^{107}$.

Macdonald'a nazaran ${ }^{108}$, yolcunun otelde evinde olduğu kadar teyakkuz göstermesi kifayet eder; diğer müelliflerle ${ }^{109}$ birlikte biz bu fikre iştirak etmiyoruż; filhakika yolcu otelde, oraya çeşitli şahıslanın girip çıtığın düşünerek eșyasını muhafaza ve ona nezaret için hususîi bir dikkat ve ihtimam sarfeylemelidir.

Şu kadar ki zararn yolcunun fiiline kabili isnat olup olmadiğı tesbit edilirken otelciye ve müstahdemlerine karşı, üçüncü șahıslara karşı oldti* ğundar daha słk davranılmalıdır ${ }^{110}$; başka bir deyimle, yolcu otelciye ve müstahdemlerine itimad edebilmeli ve onlara karşı da üçüncü şahıslara karşı alması lâzım gelen tedbirleri almakla mükellef tutulmamahdır; meselâ odada meydanda bırakılan bir saati bir üçüncü şahıs çalarsa bu; yolcuya kabili isnat olabilir; fakat oda hizmetçisi çalarsa vaziyet böyle değildir.

Bazan yolcunun fiili başka sebeblerin inzimamıla zararın husule ge!mesinde âmil olmuş yahut da sadece zarann artmasında rol oynamış olabilir; bu gibi ihtimallerde otelci mes'uliyetten tamamen kurtulamaz; yalnız bizzat yolcunun sebebiyet verdiği nisbette zarann tazminle mükellef ol. maz ${ }^{11}$. Eğer yolcunun fiili kusurlu ise tazminatın tenkisinde bu kusurun

104) RO 39 II 725; Vaud Kanton Mahkemesi JdT, 1895, sh. 230 a da bk.

105) RO 37 II 195/196, "Geith und Schnell c. Troxler".

106) Oser-Schönenberger, Art. $487, \mathrm{Nr}, 22$.

107) Chaubert, sh. 201.

108) Sh. 21.

109) Chaubert; sh. 185; Paul Buchli, sh. 39, 41; Bècker, Art. 487, Nr. 27; Ernst, sh. 67.

110) Chaubert, sh. 194-197.

111) Bk. Chaubert, sh. 189; Pétermann, sh. 12; Federal Mahkeme, RO 30 ò II 60-62 "Colteletti c. Hafen", (bir otomobilin yanma benzin tenekeleri konulması); RO 46 II 120, "Wiener Werkstätte A. G. c. Marbach", (bavulun muhtevasının yüksek kıymette oldư̆unun bildirìmemesi); Oser-Schönenberger, Art. 487, Nr. 23. 
ağırlı̆̆ da gözönünde tutulur; diğer taraftan, otelci veya müstahdemlerinia de kusuru bulunması takdirinde bu kusur yolcunun müterafik kusuru ile tartilarak tazminat tayin edilir ${ }^{112}$.

b) Yolcu kendisini ziyarete gelen ve refakatinde bulunan şahıslarıx fillerinin neticelerine katlanmahdır.

Ziyaretçi, yolcunun sarih veya zımnî nzasıyla geçici olarak onu görmeğe gelen kimsedir ${ }^{113}$; bu, yolcunun bir ahbabı, ona mektup veya ssmarladığı şeyleri getiren bir şahıs olabilir. Fakat bizzat otelcinin kendi teșebbüsüyle yolcuya getirdiği veya tavsye ettiği şahıslar ziyaretçi sayılamaz ${ }^{114}$. Eğer yolcu bir otel müstahdemini ahlâka mugayir bir maksat, meselâ geceyi beraber geçirmek, için odasına dâvet etmişse o da ziyaretçi addo. lunmalıdır ${ }^{115}$.

Kimlerin yolcuya refakat edenler olarak tavsif edileceğine gelince. bu hususta her şeyden önce onun bu sıfatla otel defterine kaydettirdiği kim. seler olup olmadığına bakılmahdır116. Yolcunun beraberinde bulunan ailesi efrad, müstahdemleri ona refakat edenler kategorisine girer. Grup halinde seyahat edenler de hesaplarm ayn ayn ödeseler bile birbirlerinin refikidirler ${ }^{117}$.

2. Zarann mücbir sebeblerden husule gelmesi.

Mücbir sebeb (force majeure, höhere Gewalt) mefhumunu tayin etmek için muhtelif nazariyeler ileri sürülmüştür ${ }^{118}$. Sübjektif nazariye mucibince $^{119}$, otelcinin âzami dikkat ve ihtimamu gösterse dahi önceden der-

112) Becker, Art. 487, Nr. 27.

113) Oser-Schönenberger, Art. 487, Nr. 21; Chaubert, sh. 205.

114) Becker, Art. 487, Nr. 25; Chaubert, sh. 206; Pêtermann, sh. 13.

115) Paul Buchli, sh. 41; Chaubert, sh. 206; Pétermann, sh. 13.

116) Becker, Art. 487, Nr. 24.

117) Becker, Art. 487, Nr. 24; Chaubert, sh. 205.

18) Bu nazariyelerin teferruatı için bk. Giovanoli, sh. 12-88; Stark, sh. 160-168; Hüseyin Avni Göktürk, Türk hususî hukukunda mụ̈chir sebeb ve fevkalâde haller, Adliye Cerldesi, 1936, sh. 1165 ve mìt.

119) L. Goldschmidt, Das receptum nautarum, couponum, stabulariorum, Goldschmidts Zeitscrift für d. ges. Handelsrecht, 3 (1860), sh. 93 ve müt., Macdonald, sh. 22-23; Rossel, sh. 560, no. 2. Chaubert'e nazaran (sh. 160 ve müt., hususiyle sh. 167) borçlunun mes'uliyetinin müchir sebeb mústesna olmak üzere tesadúfì hale de teşmil edilmesi, onun kusuru olmadığını ispatının ağırlaştrrilmasından başka bir şey değfldir; böyle bir vaziyette, borçlu umumi surette kusuru olmadığını değil, zararnn muayyen bir sebebten ilerj geldiğini ve bu 
piş etmesine ve aldığı en titizce tedbirlerle dahi mani olmasına imkân bulunmayan hâdiseler mücbir sebep vasfını taşırlar. Bu nazariye müchbir sebeble kusuru olmamay, yani alelâde tesadüfî hali (umulmamazlı, casfortuit, Zufall) kanştırdığı için bugün terkedilmiştir. BK. md. 478 de sübjektif nazariyeden mülhem olunmadı̆ı muhakkaktır; zira sübjektif nazariye kabul edilseydi, mezkûr hükümde mücbir sebepten ve otelciyi mes' uliyetten kurtaran diğer sebeblerden bahsedilmesine hacet kalmazdr: sadece, otelcinin kusuru olmadığın isbatla mes'uliyetten ber'i olacağmın: beyanı kâfi gelirdi.

Gerçi bugün hâkim olan objektif nazariyenin taraftarlani ${ }^{120} \mathrm{da}$ mücbir sebebin bir nevi tesadüfî hal olduğunu teyid etmekfedirler; so ka. dar ki bu, hususì şiddette bir tesadütí haldir, yani alelâde tesadüfî halle: mücbir sebep arasında bir keytiyet değil kemiyet tarkı mevcuttur ${ }^{\mathrm{tz1}}$. Objektif nazariyenin müdafilerine göre, mücbir sebep, otel işletmesine mer. but bulunmayan, objektif bakımdan önceden derpiş edilmesi mümkü:s: olmayan ve hariçten mukavemet edilemez bir şiddetle kendisini gösteren fevkalâde bir hâdisedir. Yıldınm düşmesi, feyezan neticesinde oteli. su basması, hariçtèn sirayet eden bir yangn, bir ihtilâl esnasında otelin:

sebebi önlemenin kendi borçları sahasına girmeđĭgini ispat eđecektir. Binaenaleyh Chaubert de bir nèvi șibjektif nazariyeye taraftarin deniletilit. Chaubert'in müiafaa ettiği görtișe benzer bir hal sureti tBK. mu 1912 tadilinde nak.liyecinin mes'uliyeti bahsinde kabul edilmiştfr. Bk. md. 438 1. I

120) Bk. Exner, Volkmar ve Rumelin'in yukarida not 3 ve 5 te zikredilen tetkikleri; Giovanoli, sh. 253; ayni mürellif ZSR, N. F. 54 (1935), sh. 12 ve 20-22; Karl Oftinger, Schweízerisches Haftpflichtrecht, Bd. I. Zürich 1940, sh. 86 ve mut. ; Oser-Schönenberger, Art. 487, Nr. 28; Becker, Art. 487, Nr. 31; Paul Buchli, sh. 42-43, Federal Mahkeme de nisbeten yeni kararlarinda objek-. tif nazariyeye temayul etmiştir, bk, RO 57 II 511, "Politische Gemeinde Rapperswil c. Spiller".

121) Giovanoli, sh. 226-227; Oser-Schönenberger, Art. 487, Nr. 26; Pauf: Buchli, sh. 42. Buna mukabil Stark'a göre (şh 146-148), mucbir sebeb. siddeti: bakımından değil çifte tesadŭfü (doppelde Zufălitgkejt) tazammun etrmesi ba. kumindan alelâde tesadüfí halden aymhr; yaní múcbir sebeb sayılan hădîse hem? umumî olarak bir tesadüfi hal vasfın tașmali, lem de objektif mes"uliyet sebebinin husule getirmeğe salih olduğu neviden fïr netice olmamaJidır; Stark: hâdisenin mücbir sebeb olarak tavsif eđilebilmesi iẹin uçüncỉ bir sart da koymaktadır: hâdise, mes'uliyet sebebi ile zarar arasındaki illĭyet rabıtasın kesmelidir (Unterbrechung des Kausalzusammenhanges). Stark'un nazariyes, müc-. bir sebeb mefhumunu illiyete müstenid mes'uliyet halleri bakımmdan izah içis kurulduğundan daha ziyade bir netice mes'ulfyetf karakterini taşyan otelcimin mes'uliyeti hakkında tatbike pek elverișli değgildir. Bk. Stark, sh. 160 ve 168 . 
yağma edilmesi birer mücbir sebep teşkil edebilirler; buna mukabil, oteldeki elektrik kablosunda bir kısa devre olması, su borulannın patlama. sı, otelin içinden yangın çıkması ${ }^{122}$, otel hırsızlarının yolcunun eşyasııı ça.lması kaideten mücbir sebep addolunamaz. Zararı sebebi meçhul kaldığı takdirde mücbir sebebin mevcudiyetini iddia etmek kabil değildir'23.

Giovanoli124, hâdisenin otel işletmesine bağh tehlikelerle alâkası olmaması ve fevkalâde mahiyet arzetmesi kıstaslarma, mücbir sebep tarj. finde yer verilmesinin aleyhindedir; bu müellife nazaran, bunlar ancak hâdisenin objektif bakımdan mukavemet edilemez mahiyette olduğuna bir delil teşkil edebilirler; binaenaleyh, sübjektif bakımdan önceden dępiş edilmesi ve yenilmesi mümkün olmayan hadiseler alelâde tesadüfi hal, objektif bakımdan önlenmesi mümkün olmayanlar ${ }^{125}$ ise mücbir sebep olarak tavsif edilmelidir ${ }^{126}$. Zamanumızda kusurun objektifleștirilmesi cereyanı127 karşısında, Giovanoli'nin nazariyesinin mücbir sebeple kusuru olmamayı tefrik bakımından pek tatminkâr olmadığı söylenebilr.

3. Zararın getirilen eşyanın mahiyetinden mütevellid olması.

Zararın getirilen eşyanın mahiyetinden mütevellid olması hallerini şöylece sıralamak mümkündür ${ }^{128}$ :

a) Zarar, münhasıran esyanın mahiyetinden ve tabii kuvvetleris: normal tesirinden neş'et etmiş olabilir; şeyin kendiliğinden çürümesi, tebahhưr etmesi, kuruması, ateş alması gibi. Fakat meselâ eşya odanun aşın rutubeti yüzünden çürümüşs otelci gene mes'ul tutulur.

b) Zarar, münhasıran esyanın ayıplı olmasından ileri gelebilir; me-

122) Eğer yangın otelde kulJanılan kömürün içinde kalmış olan dinamit kartuşunun infilakinden çıłmişsa mücbir sebeb saylabilir; Chaubert, sh. 170; Pétermann, sh. 14 .

123) Chaubert, sh. 174; Pétermann, sh. 14.

124) Sh. 228-236.

125) Yani hâđise, ilim ve tekniğin halihazır seviyesine göre alınması kabil tedbirlerle (bu tedbirlerin alımması otelci için bir kusur teşkil etmese dahi) önlenemeyecek siddette olmalıdır; demek oluyor ki, otelei, kusuru olmaksızın bu gibi tedbirleri almamış ve fakat bu tedbirleri alsaydi hâdise önlenebilecel idiyse gene mes'uldür : Giovanoli, sh. 236-238.

126) Giovanoli, sh. 227.

г2\%) Bu hususta bk. Oftinger, sh. 105 ve müt.

128) Chaubert, sh. 208-211; Paul Buchli, sh. 43-44; Oser-Schönenberger, Art. 487, Nr. 29; Becker, Art. 487, Nr. 30; Pétermann, sh. 14. 
selâ hasta bir köpek otele geldikten sonra hastahğı neticesinde ölmüştür; yahut kınlacak eşyanın ambalajı iyi yapılmamıs ve otel müstahdem:,ne bu eşya taşınıken hususi bir dikkat gösterilmesi için tenbihte bulunulmamıștır.

c) Yolcu tarafindan getirilen şeylerden birinin ona ait diğer bir seye zarar vermesi de kabildir. Meselâ, yolcunun bavulu içine koyduğu ìyi kapanmamış bir şişeden dökülen mayi onun çamaşıriannı lekelemiştir; yahut yolcunun köpeği onun eß̉iselerini parçalamıştır.

Eğer bir yolcuya ait şeye başka bir yolcụnun sahip olduğu şey zarar verecek olursa otelci mes'uliyetten kurtulamaz; bittabii ekseriya zarar veren şeyin sahibinin de mes'uliyeti cihetine gitmek, ezcümle BK. md. .56 yı ileri sürmek mümkün olur.

4. Taraflann mukavele ile otelcinin mes'uliyetini bertaraf veya tah fif etmesi.

Otelcinin hususî mes'uliyetini derpiş eden hükümler âmir mahiyette değildir; bunlann hilâfına mukkavele yapmak imkânr vardır ${ }^{29}$. Gerçi yolcularn emniyeti bakımından mezkûr hükümlerin âmir mahiyette ol-ması arzuya şayań sayılabilirdi; fakat bugünkü hal sureti de büyük mahzurlar arzetmez; zira otelci müşterilerini kaçırmak endişesi ile onlara mes' aliyetini bertaraf edici mukaveleler teklif etmekten çekinir ${ }^{130}$; diğer taraftan, bahis mevzuu mes'uliyet yalnız' mamelekî menfaatleri alâkalandırdığından, bertaraf edilmesinde amme intizamı müteessir olmaż ${ }^{131}$.

Otelcinin hususi mes'uliyeti ancak BK. md. 99 ve md. 100 f. III deki hudutlar dahilinde mukavele ile ortadan kaldınlabilir veya hafifletilebilir132. Böyle bir mukavele yapldığı takdirde dahi otelcinin haksız fiillerinden dolay mes'ul edilmesi imkâmı baki kalır ${ }^{133}$. Eğer otelci yolcunun zaruret halinde bulunmasin istismar ederek onunla mes'uliyetini bertaraf edici bir mukavele yapmışa, halin icaplanna göre bu mLkavele âdaba mugayir ve BK. md. 20 mucibince batıl sayılabilir ${ }^{134}$.

129) Chaubert, sh. 212-214; Paul Buchli, sh. 37; Oser-Schönenberger, Art. 487, Nr. 19; Becker, Art. 487, Nr. 34; Art489, Nr. 1. Aksi fikirde Jacottet, Manuel du droit fédéral des obligations, Neuchåtel 1884, sh. 274.

130) Pétermann, sh. 16.

131) Paul Buchli, sh: 38

132) Paul Buchli, sh. 38; Becker, Art. 487, Nr. 34; Oser-Schönenberger:

Art. 487, Nr. 19; Pétermann, sh. 16.

133) Oser-Schönenberger, Art. 487, Nr. 19; Pétermann, sh. 16.

134) Becker, Art. 489, Nr. 4.

A. Huk. F. Der. 
BK, md. 480 cümle 2 ye tevfikan, otelci veya hanc, BK. md. 478 : 479 da derpiş edilen mahiyette bir mes'uliyet deruhde etmediğini veya mes'uliyetini bu hükümlerde bahsi geçmeyen bir şarta talik ettiğini yapıștırdığı ilânlarda bildirse bile, mes'uliyetten kưtulamaz. Kanun vazıı otelcinin tek taraflı beyanlanna yolcunun zımni rızasının inzimam ettiği suretinde yapılacak tefsirlere mani olmak için bu hususu tasrih etmek lüzumunu hissetmiştir. Filhakika çok defa yolcu otelcinin yapıştırdığı ilânlara dikkat etmez, etse bile o ilânın yazılı olduğu dili bilmeyebilir; ilânlara hüküm izafe olunsaydı otelcinin hususî mes'uliyeti hakkındaki kaidelerden kolayca sıynlması mümkün olurdu. Otelcinin yolcunun eşasın istasyona götüren kimselerin kendi müstahdemi olmadıği hususundaki ilânı hakkında BK. md. 480 cümle 2 tatbik edilemez ${ }^{135}$; yani böyle bir ilân muteberdir ve eşya yolda kaybolsa otelci mes'ul edilemez; çünkü eşyanın istasyona taşımması muhakkak surette otel işletmesine bağh hizmetlerden değildir. Diğer taraftan, faraza yolcunun odasından çıkarken kapıyı kilitlemesi gerektiği ilân edilmişse bu da muteberdir ve yolcunun müterafik kusuru olup olmadığını tayinde rol oynar ${ }^{136}$.

Yolcunun otele inince doldurduğu fişlerde ufak harflerle basılmış mes'uliyetten beraet ettirici sartlara zımnen nza gösterdiği tarzındaki iddialar da hâkim tarafindan kolaylıkla kabul edilmemelidir ${ }^{137}$.

\section{Yolcunun zarann otelciye vaktinde bildirmemesi.}

BK. md. 480 cümle 1 mucibince "yolcu zaranna vakıf olur olmaz otelci veya hancıya bildirmezse hakkı sakıt olur". Bu hüküm otelcinin zararn hakikaten varit olup olmadiğ ve muhtemẹl faili bulmak hususunda gerekli araştırmalara vaktinde girișebilmesini temin maksadiyla sevkolunmuştur ${ }^{138}$.

Yolcu zararna vakıf olur olmaz hemen otelciye bildirmelidir. Kisurlu b:r gecikme olup olmadı̆ı halin icaplanna ve zarann büyüklüğünc göre tayin olunur ${ }^{139}$; ezcümle zarar büyükse ve yolcu otelden uzaklaşmış bulunuryorsa mektup yerine telefon veya telgrafla bildirmek lâzım gelir. Zaran haber verme mükellefiyetinin vaktinde yerine getirilmediğini isbat

135) Becker, Art. $489, \mathrm{Nr} .3$.

136) Chaubert, sh. 214 ve 217; Pétermann, sh. 16.

137) Becker, Art. $489, \mathrm{Nr} .1$.

138) Chaubert, sh. 266; Paul Buchli, sh. 44; Oser-Schönenbergèr, Art. $489, \mathrm{Nr} .1$.

139) Becker, Art. 489, Nr. 5; Oser-Schönenberger, Art. 489, Nr. 1. 
otelciye terettüp eder ${ }^{140}$; çünkü burada dava hakkını ortadan kaldıran bir hal bahis mevzuudur; aksi takdirde, yolcuya ménfỉ bir hususun, zara$n$ iddia ettiğinden daha önce öğrenmediğinin ispatı yüklenmiş olurdu ki bu, onun için çok müşülât arzederdi.

Zarar bizzat otelciye veya onun bu hususta salâhiyetli mümessitine bildirilmelidir ${ }^{141}$; otel müdürü veya kâtibi bu hususta salâhiyetli sayłlabilir; takat oda hizmetçisi veya kapıc için ayni sey söylenemez; ancak bu sonuncular, salâhiyetli șahıșara ihban naklettikleri anda ihbar yapulms saylur.

Ihbar mükellefiyeti hukukumuzda, Alman hukukunun aksine, otelciye emanet edilmiş olan eşyanın' uğradığ zarar hakkında da carîdir. Alman hukukunda, otekinin kendi yedinde bulunan eşyanın uğradığı zaran bileceği mülâhazasiye, bu eşya bakımundan ihbar mükellefiyetinden sarfinazar edihniştir ${ }^{142}$. Halbuki Becker'in işaret ettiği veçhile ${ }^{143}$, bu eşya yolcuya iade edilirken bir kanșlkhk veya eksiklik olmus ve yolcu bunun otelden aynldiktan sonra farkuna varmış ise, otelcinin zarardan vaktinde haberdar olmakta menfaati vardir.

thbann yapılmamass yolcunun BK. md. 478 ve 479 mucibince dava açma hakkım sukut ettìrir. Buna mukabil, onun umumi hükümler mucibince dava ikame etmesine bir mani yoktur ${ }^{144}$.

IV. - Mes'uliyetin Tahdidi

Eski zamanlarda seyahatler ekśeriya zanuret icabı yapliyor ve yolcular beraberlerine basit ihtiyaçlan için lâzım olan eşyadan fazlasın almiyorlard. Halbuki XIX. asnn ikinci yansindan sonra bir taraftan nakil vastalarnin diğer taraftan otelciliğin inkişah neticesinde çeşitli maksatlarla seyahat edilměge başlandı; yolcular artk kuymeti fazla menkul eşyalann da yanlannda taşyorlardı; müşterileri lüks hayat sümmeğe ahşık büyük oteller ortaya çıt.. Bu vaziyet karşısında muhtelif memleketlerin kanun vazılar, o zamana kadar hudutsuz olan otelcinin ağır mes'uliyetini tahdit etmek lüzumunu duydular. Mes'uliyeti tahdit hususunda otelcilere en ziyade müsait davranan Isviçre BK. oldu. Bu kanunda ve dolaysiyle BK. muzda mevcut mes'uliyet tahditleri şunlardır:

140) Becker, Art. 489, Nr. 5; Osẹ-Schönenberger, Art. 489, Nr. 1.

141) Becker, Art. 489, Nr. 6; Chaubert, sh. 266-267.

142) BGB $\$ 703$, culmle 2. Staudinger-Nipperdey, \& 703, Nr. 6 ya bk. Isviçre hukukunda ayni fikirde Ernst, sh. 95.

143) Art. 489 , Nr. 6.

144) Chaubiert, sh. 267. 
1. Tazminatın tahdidi.

a) İsviçre hukukunda hâkim olan görüş mucibince ${ }^{145}$, otelci, ha sara uğrama, telef olma veya çalınma yüzünden yalnız eşyanın zatına müteallik olmak üzere husule gelen zaran ödemekle mükelleftir; başka bır deyimle, tazminatın âzami hududunu eşyanın objektif kıymeti, yani zarara uğradığı andaki mübadele kıymeti teşkil eder. Yolcu eşyanın hasara uğraması, telef olması veya çalınması yüzünden maruz kaldığı kâr mahrumiyetinin ${ }^{146}$, yahut şeyin kendisi için arzettiği mânevi kuymetin (valeur d'affection), şeyin yerine başkasını ikame etmek için ödediği bedelin şeyin kıymetinden fazla olan kısmının, şeyi araştırmak maksadıyla, veya otelciyi dava etmek dolayssiyle ikametinin uzaması neticesinde vaptığı masrafların ödenmesini isteyemez. Tazminatın böylece tahdidi BK. md. 478 de kullanılan ifade tarzıyla ve burada ağıt bir mes'uliyetin bahis mevzuu olmassyla hakklı gösterilmeğe çalışılmaktadır.

Alman ve Fransız hukukundan mülhem olan bazı müellifler ise bu hal tarzın hakkaniyete uygun bulmamaktadırlar; onlara nazaran de lege $\operatorname{lata}^{147}$ veya hiç olmazsa de lege ferenda ${ }^{148}$ otelci yalnız şeyin hasara uğ. raması, telef olması veya çalınması yüzünden doğrudan doğruya uğranı. lan zaran değil fakat dolaysile duçar olunan zararı da uygun illiyet ra. bıtası mevcut olduğu nisbette ödemeğe mecbur kılınmalıdır.

b) BK. md. 478 cümle 2 ye tevfikan otelcinin ağır mes'uliyeti her bir yolcu için kaideten 100 lirayı tecavüz edemez.

Birden fazla yolcu, meselâ bir ailenin efradı veya srup halinda seyahat edenler müş̧tereken otelci ile tek bir mukavele yapmış olsalar dahi 100 liralık âzami had herbiri için ayn ayin . hesaplanmalıdır ${ }^{14 \%}$; çünkü otelcinin mes'uliyeti mukaveleye değil kanuna müsteniddir; ka!dı ki, otelci ücretin hesabmda her şahsı ayn ayrı nazara aldığına göre hetbiri için katlanacağı risklerin karşılığın da temin etmektedir.

145) Oser-Schönenberger, Art. 487, Nr. 32; Becker, Art. 487, Nr. 19; Ernst, sh. 60 ve müt. ; Stiffler, sh. 72 ve müt. ; Federal Mahkeme, RO 36 II 62, "Colteletti c. Hafen"; 37 II 196/197, "Geith und Schnell c. Troxler"; Neuchâtel Kanton Mahkemesi, Rev. Jud, 1893, sh. 218.

146) Meselâ seyyar tüccar memuru beraberinde getirdiğ̀ nümunelerin çalınması neticesinde kârlı bir akit yapmak imkânım kaybetmiştir.

147) Von Tuhr, Ṕartie générale du Code fédéral des obligations, premict volume, 2 e èd., Lausanne 1933, sh. 98 not 16 .

148) Paul Buchli, sh, 31-32.

I49) Oser-Schönenberger, Art. 487, Nr. 33; Becker, Art. 487, Nr, 20; Paui Buchli, sh. 30; Chaubert, sh. 247. Aksi fikirde Macdonald, sh. 36. 
Diğer taraftan, 100 liralık âzami had, yolcunun otelde ikameti esnasında vukua gelen birbirinden müstakil mahiyette muhtelif zarar verici hadiselerin hepsi için birden değil herbiri için ayn ayn bahis mevzuudur ${ }^{150}$.

c) Eğer zarann husule gelmesinde bizzat otelcinin veya müstahdemlerinin bir kusuru varsa, onun mes'uliyeti artk 100 liraya inhisar etmeyip hudutsuzdur. Otelcinin yolcuya odasin kilitlemek imkânını temin etmemesi151, hırsıżlıktan sabıkalı olduğunu bildiğj bir kimseyi oteline kabul etmesi ${ }^{152}$ ona bir kusur olarak izafe olunabilin. Kusurun isbatı meselesine gelince, Oser-Schönenberger'e nazaran ${ }^{153}$, otelci, eşya hak. kındaki akdî bir borcuna aykın hareket etmişse, kusuru olmadığını is batla mükelleftir; akdì bir borca muhalefet bahis mevzuu değilse yolcu otelcinin kusuru olduğunu isbata mecburdur.

Otelciye karşı umumi hükü̈mlere müsteniden tazminat davası açlirr. sa, artık o yalnız eşyanın objektif kıymetini değjil, yolcunun uğradığı bütün zaran uygun illiyet rabıtasının hudutlan dahilinde ödemekle mükel. lef olur; bu takdirde otelciden mậnevî tazminat istẹnmesi de mümkün olabilir.

2. Krymetli eșya hakkındaki hususî hüküm.

a) BK. md. 479 cümle 1, kıymetli eșva hakkında otelcinin ağır mes'uliyetini, bazı şartların tahakkukuna bağlı kılmak suretile, doğumu bakımından tahdit etmektedir. Buna mukabil bu şartlann mevcudiyeti halinde mes'uliyetin neticeleri daha şümullüdür; yani artık 100 liralık âzamî had burada bahis mevzuu olmaz. Şimdi mezkûr şartlar üzerinde duralim: hil olur:

๕a) Eşya kıyṃetli olmalıdır. Kıymetli eşya mefhumuna şunlar da

I) Mühim miktarda para. Paranm mühim miktarda olup olmadı̆g otelin sınıfına ve o otele muntazaman inen yolculann içtimaí mevkïine göre tayin olunur ${ }^{154}$.

II) Kıymetli evrak, yani tecessüm ettirdiği hakkın kendisinden ay-

150) Oser-Schönenberger, Art. $487, \mathrm{Nr} .33$,

151) Oser-Schönenberger, Art. 487, Nr. 34.

1.52) Temyiz Mahkemesi, 4. H. D., 13/11/1945 tarih ve $2451 / 4126$ sayl karar (Tepeci, sh. 614-615).

153) Art. $487, \mathrm{Nr} .34$ 
n olarak dermeyanma ve devrine imkân olmayan senetler. Alelâde isbat vasitalan, isbat edilmesine hizmet ettikleri hak çok kıymetli olsa bile bu kategoriye girmezler, hatta Chaubert'e nazaran ${ }^{155}$ bunlan sair kıymetli eşya meyanında da saymak kabil değildir.

III) Sair kıymetli eşya. Bunlar, yappıldıklan maddenin mahiyeri, nadir bulunur olmalan, eskilikleri veya san'at eseri vasfını taşımalanı gibi sebepler yüzünden ağrrlıklarına ve hacimlerine nisbetle kıymeti büyük olan şeylerdir156. Eşyanın kıymetli olup olmadığı münferit parçalar ba. kımından tayin edilmelidir ${ }^{157}$; yoksa çalınan bir sandıkta bulunan şeylerden bazılan kıymetli bazılan kıymetsiz olabileceği gibi bir şeyden çok miktarmin bir arada bulunması dolayısile kyymet arzetmesi ${ }^{158}$ de ona kıymetli eşya vashnın tanınmasını icap ettirmez. Eşyanın kıymetli. olup olmadığın tayininde de otelin sınıf, oraya inen yolcuların seviyesi ve. muamelâtta cârî telâkki gözönünde tutulur.

bb) Eşya bizzat otelciye veya onun bu hususta salâhiyetli mümessiline emanet, yani fiilen teslim edilmiş bulunmahdır. Kıymetli eşyayı kabule salâhiyetli mümessillerin çevresi; alelâde eşyayı kabule salâhiyetli olanlannkinden daha dardır; ancak otel müdürü, kâtibi veya veznedarn bu is için salâhiyetli sayılabilir159. Eşyanın tevdii otelcinin veya mümessilinin hizmette bulunduğu sırada, mutad is saatlerinde yapılmalıdır. Otel hancinde bir gezinti esnasinda otelciye emanet edilen kıymetli bir yüzüğün veya gece yansından sonra otelin gece kapıcısına makbuz mukabili

154) Oser-Schönenberger, Art. 488, Nr. 2; Tessin Istinaf Mahkemesi, SJZ, 40 (1944), sh. 242; Federal Mahkeme, RO 37 II 193 ve müt, "Geith und Schnell c. Troxler"; 39 II 726/727, "A. G. Neues Stahlbad St. Moritz c. Farpner"; Temyiz Mahkemesi 4. H. D. yukarıda not 152 de zikredilen kararunda 200 : lírayı mühim mjktarda para addetmiştir Ticaret Dairesi ise, miktarı üzerinde durmaksızın paranin otelciye tevdı edilmemesi halinde otelcinin mes'ul olmayacağı içtihadında bulunmuştur 22/12/1951, E. 951-6200/K. 6403; Türk İçtihatlar Külliyatı, 1952, cilt 1, no. 361, sh. 223-224; bu içtihat "mühim miktar" șar. tını aramadı̆̆ı için tenkide şayandır.

155) Sh. 246.

156) Oser-Schönenberger, Art. 488, Nr. 4; Chaubert, sh. 250-253; Becker, Art. 488 , Nr. 2.

157) Oser-Schŏnenberger, Art. 488, Nr. 4; Chaubert, sh. 251; Federal Mahkeme, RO 36 II 55 ve müt., "Colteletti c. Hafen"; 46 II 118/119, "Wiener Werkstätte A. G. c. Marbash".

158) Meselâ 200 kilo kahve.

159) Bk. Oser-Schönenberger, Art. 488, Nr. 5; Zürich Yüksek Mahkemesi, BIZR, 21 (1922) sh. 100. 
werilẹn mühim miktarda paranm kaybolması dolayısile otelci BK. md. -479 a binaen mes'ul tutulamaz ${ }^{160}$,

Esyanın otelciye veya mümessiline tevdii neticesinde otelci vedia hükü̈mlerì mucibince mes'ul kılınacağını ve kusuru olmadığın ispat suretile mes'uliyetten kurtulacağın iddia edemez; o, BK. md. 478 de sayılan mes'uliyeti ortadan kaldıncı sebèblerin mevcudiyetini ispat etmedikçe eşyanm hasara uğramasından, telef olmasından veya çalınmasından doğrudan doğruya doğacak zaran hudutsuz olarak, yani 100 liradan fazla da . olsa tazminle mükelleftir ${ }^{161}$.

cc) Otelci esyayn emaneten kabulden imtina etmişse gene mes'uliyeti hudutsuzdur (BK. md. 479 cümle 2); o, esyay muhafaza için gerekli tesisata sahip olmadiğını mazeret olarak ileri süremez ${ }^{162}$; otelcilik eden kimse kıymetli esyayı muhafaza etme ğj üzerine almak ve bunun için gerekli vasitalan, meselâ bir kasayı, temin etmej mecburiyetindedir. Eğger otelci kıymetli esya için mes'uliyet deruhte etmek istemiyorsa ya yolcuyu kabul etmemeli veyahut da onunla mes'uliyeti bertaraf edici bir mukavele yapmahder.

dd) Otelciye emaneti gereken kıymetli eşya tevdi edilmemisse, otelci ancak kendisinin veya müstahdemlerinin kusuru halinde bu eşyanın uğradığı zarardan hudutsuz olarak mes'ul olur (BK. md. 479 cümle 1).

b) Yolcunun kendi nezdinde saklayabilmesi lâzımgelen kıymetli eşya için otelci, bu eşyanın kendisine emanet edilmesine hacet olmaksizın, BK. md. 478 deki şartlar dahilinde mes'ul olur ${ }^{163}$ ve mes'uliyetinin âzami haddi 100 liradır (BK. md. 479 son cümle).

Bu çeşit kıymeth eşyanın hangileri olduğunu tesbit için gene otelin sinifi, nev'i, yolcumun ikamet müddeti, mahallî örf nazara alınmalıdır. Me. selâ bir kış istasyonundakj lüks bir otelde kalan yolcu binjerce lixa kıymetindeki mücevheratın, saatini, kürkünü, tuvaletlerini kendi nezdinde sals-

160) Bk. Federal Mahkeme, RO 33 II 263, "Spelterini c. Seiler"; Reichs:gericht, RGE, 99, Nr. 20 .

161) Chaubert, sh. 254; Paul Buchli, sh. 29. Temyiz Mahkemesi 4. H. D. nin 30/6/1942 tarih ve 2199/1887 sayli kararina da bk. (Tépeci, sh, 613).

182) Oser-Schönenberger, Art. 488, Nr. 6; Chaubert, sh. 254; Becker, Art. $488, \mathrm{Nr} .3$.

163) Bk. Temyiz Mahkemesi Ticaret Dairesinin yukarida not 154 de zikredilen karari; bu kararda Bk. md. 479 son cümlede ardiye mukavelesi jle alâkalı Bk. ma. 474 e atıf yapldığının beyan edilmesi her halde bir tertip hatasından îeri gelmektedir; atif md. 474 e değil $\mathbf{4 7 8}$ edir. 
layabilmelidir. Winkler'in fikrince ${ }^{164}$, yolcunun odasından çkarken oradz bıraktığı eşya bu kategoriye girmemelidir; çünkü eşyanın adada brakı!ması ona yolcunun devaml surette ihtiyacı bulunmadığını gösterir. Chaubert ${ }^{165}$ haklı olarak bu fikri şok dar bulmaktadır; yolcu sade devamlı surette ihtiyacı olan şeyleri değil, serbestçe tasarruf etmesi gereken ve her ihtiyacı olduğu sefer otel bürosuna müracaat etmesi zahmetli olan şeyleri de nezdinde saklayabilmelidir. Diğer taraftan çok para harcayan zengin bir șahıs üzeninde mühim miktarda para bulundurabilmelidir.

c) Ĕger yolcunun kendi nezdinde saklayamayacağı neviden kıymetli esya otelcinin imtina olmadığı halde ona emanet edilmemiş ve bu eşyanın hasar veya ziyaunda otelcinin ve adamlarmm kusuru bulunmamıs ise otelcinin hususî mes'uliyeti bahis mevzuu olamaz ${ }^{166}$.

3. Otelcinin mes'uliyetine 100 liralık âzami had konulmasının tenkid: .

Fỉkrimizce, yolcunun kendi nezdinde kalan eşyası için otelcinin mes'uliyetine 100 liralık âzamî bir had konulması tenkide şayandır: Fil . hakika, bu haddin basit bir han için de en lïks bir otel için de ayni olması hakkaniyete aykmindır. Diğer taraftan, bu gibi muayyen bir rakamla ifade edilen hudutlar para değerinin düşmesiyle mânalannı kaybetmekte vọ bunlan sık sık değiştirmek zarureti ortaya çıkmaktadir. Bugün lüks bir otelde binlerce liralık kürkünü çaldıran müssterimin zarann otelcirnin vereceği 100 liralık tazminatla telâfi etmek mümkün değildir; halbuki böy! ’ bir otele inen müşteri otelciye yüksek ücretler ödemektedir ve eşyasıının emniyet içinde olmasını istemeğe haklıdır. Bu mahzurlan, Rossel'in tavsiyesi veçhile ${ }^{167}$, otelcinin ve müstahdemlerinin kusurunun ispatinda müş.külpesent davranmamak suretile önlemek ${ }^{168}$ kabil değildir; zira bu kusurun ispatında ne kadar az müşkülpesent davranılsa gene büyük güçlük vardır; zaten bunun içindir ki otelcinin objektif mes'uliyetínin kabulü cihetine gidilmiştir.

Bnaenaleyh, otelciye emanet edilmesi. lâzım gelmeyen eşya için de. 100 lixalık âzami had kaldırılmalıdır ${ }^{169}$. Mes'uliyetin bờle bir hadde tấb: kılınmaması kıymetli olmayan eşya bakımından büyük bir ehemmiyet ar-

164) Revue suisse des Hôteliers, 1914, no. 12.

165) Sh. 256-257.

166) Oser-Schönenberger, Art. 488, Nr. 9.

167) Sh. 561 .

168) Otelci, kusuru ispat edilirse, halihazırdaki sisteme göre de; hudut-. suz surette mes'ul olur.

169) Giovanoli (sh. 216 ve 253 ) de 100 liralık azami haddin aleyhindedir: 
zetmez. Kıymetli eşyaya gelince onun kaideten otelciye tevdii lâzım gelir; tevdi edilen esya için halen de hudutsuz mes'uliyet mevcuttur; kıymetli esyanın ne olduğu her otelin seviyesine göre tayin edileceğinden ve tevdi odilmeyen kıymetli esya için de hususi mes'uliyet bahis mevzuu olmayacağından 100 liralık âzami had kalkınca otelciye emanet edilmeyen esya. için mes'uliyetin hudutlannm tayini hâkimin hakkaniyet dairesindeki takdirine bırakılmış olacaktır; icabinda hâkirn otelciye emanet edilmemiş. olan eşyay! o otelin seviyesi bakımundan çok kyymetli sayacak ve otelciyi hususi mes'uliyetten beri kulacaktrr. Küçük bir otel için kıymetli addolusnan eşya büyük bir otel bakımmndan /bu vasfı taşımayabilir; diğer taraftan ekseriya kıymetli eşyası az bulunan kimseler mütevazı otellere, zenginliklerini teşhir etmek isteyenler de büyük otellere inerler. Teklif ettiğimiz hal tarzı kabul olunursa, her otel seviyesiyle mütenasip risklere katlanır; bunlan da aldığ ücretle karşılaması ve icabında bu risklere karşı kendisini sigorta ettirerek verdiği primleri otel ücretinde hesaba katması müinkündür. Böylelikle, âzamî haddi, para kıymetinin tahavvülleri nazara alınarak, zaman zaman tâdil etmek zarureti de ortadan kalkar. Bundan başka Fedexal Mahkeme'nin son içtihadına nazaran!70 umumî garaj sahiplerınin garajlarına konulan otomobiller için mes'uliyeti hudutsuzdur; otelcinin de hudatsuz mes'uliyeti kabul edilirse, büyük garajı olan otelcilerle garajclann mes'uliyeti arasında bir ahenk temin edilmiş olur.

Isviçre BK. 'da bizdeki 100 liraya tekabül eden 1000 franklik âzamí had otelcilerin mesleki teşekküllerinin (Société sụisse des Hôteliers) tazyiki altında konulmuștur. Fïlhakika 1881 tarihi IBK. da böylé bir had yoktu. Tâdil projesinde ise, fransız ve alman hukuku ömek alınarak sadece otelciye tevdi edilmeyen kıymetli eşya için 1000 fr. lık âzamî had kabul edilmişti; halbuki kanunun nihaî metninde bu had kıymetli olsun olmasın otelciye tevdi edilmeyen her türlü eşyaya teşmil edildi. Eğer böyle âzami bir haddin konulmásı zarurî olduğunda ssrar edilirse, hiç olmazsa bu; sadecè otelciye emanet edilmesi lâzım gelip de edilmeyen kıymetli eşyaya münhasır kılınmalıdır; yani alman ve fransız hukukundaki sistem örnek ittihaz edilmelidir ${ }^{\mathbf{7 1}}$.

170) Bk. aşağıda not 173 de zikredilen karar.

171) Chaubert, sh. 257 ve müt., sh. 274 ve Paul Buchli, sh. 29 bu fikirdedirler. Kasım 1954 taríhinde Roma'da yenilenen Beynelmilel Otelcilik Nizamnamesi ise Ingiliz sistemini kabul etmştir. Bu sistem mucibince otelci, kendisine tevdj edilen bütün eşya jçin, nev'i tefrik edilmeksizin, yăni kıymẹtli olup: olmadığına bakılmaksızın hudutsuz surette mes'uldür ve kusuru olmadığın ispat ederek bu mes'uliyetten kurtulamaz; ancak mücbir sebeb vesair mes'uli- 
V. Otelcinin Mes'uliyetinin Umumî Ahır Ve Garaj İsletenlerin Mes'uliyetiyle Münasebeti.

BK. md. 481 umumì ahır ve garaj işletenlerin mes'uliyetini şöyle tanzim etmektedir: "Umumi ahurlan ve garajlan idare edenler içerlerine konulan veya getirilen veya kendileri veya müstahdemleri tarahndan kabul olunan otomobil, hayvanat ve araba ve koşum vesair teferruatının ziya ve hasanndan ve çalınmasından zarann mudi veya onu ziyaret veya ona refaket eden veya onun hizmetinde bulunan kimseye isnadı kabil olduğunı veya mücbir sebeblerden veya tevdi olunan eşyanın mahiyetinden nes'et ettiğini ispat etmedikçe, mes'ul olur. Şu kadar ki kabul edilen otomobil ve hayvanlar ve arabalar ve onlann teferruat hakkındaki mes'uliyet, garaj ve ahur sahibine veya müstahdemlerine bir kusur isnad olunarnazsa, beherr mudi için yüz lirayı tecavüz edemez."

Bu hükmün IBK. daki aslında (md. 490), "garaj" ve "otomobil" kelimeleri mevcut değildir; nitekim matlabın türkçe metrininde de sadece "umumì ahır idare edenlerin mes'uliyeti" nden bahsedilmektedir. Fakat yakın zamanlara kadar Isviçre'de ilmi ve kazaî içtihatlar ${ }^{12}$, otomobil gibi motörlü nakil vasıtalarmı hayvanlar tarafından çekilen arabalara kıyasla. mak suretile, İBK. md. 490 in umumî garaj idare edenler hakkında da tatbik olunacağı merkezinde idi. Federal Mahkeme yeni bir kararında.173, o zamana kadar hâkim olan ve kendisinin de evvelce iştirak etmiş olduğu bu telâkkiden avnlmıştır. Yüksek Mahkeme'ye nazaran, bir kimse otomobilini koymak için, yàlnız kendisinin anahtanna sahip olduğu hususi bir mahallin (boxe) istimalinin devrini bir ücret mukabilinde temin evlerse, ortada bir kira akdi mevcuttur; yok eğer otomobil, biı garajın umumi

yetten beraat ettirici hallerin mevcudiyetini ispat etmesi kabildir. Otelciye tevdi edilmemis olan eşya için ise o, sadece kendisinin veya müstahdeminin kusuru halinde mes'ul tutulabilir. Bu sistemde yalnız kıymetli eşayı değil her tiłrlii essyay otel,ciye tevdi etmek mümliündür.

172) Oser-Schönenberger, Art. 490, Nr. 4; Becker, Art. 490, Nr, 3; Autenrieth-Gander, FJS, no. 661, sh. 3. Paul Buchli, sh. 47-48; Rossel, sh. 564; Chaubert, sh. 73; Federal Mahkeme, RO 36 II 58, cons. 2 in fine, "Colteletti c. Hafen"; 62 II 153, "Morgen c. Bucher Cie. und Meyer"; Bâle-Ville Istinaf Mahkemesi, SJZ, 46 (1950), sh. 127; Graubünden Kanton Mahkemesi, SJZ, 45 (1949) sh. 45.

173) RO 76 II 154 yahut JdT, 1951, sh. 171 ve müt. "Speich c. Milt". (Bu kararn D. Devres tarafindan yapllan bir tercumesini tstanbul Baro Dergis; sayı 10, sh. 596-603 ve Türk Içțhatlam Külliyatı, 1951, cilt 2, sh. 1277, no. 2201 de bulmak mùmkündür. Karardan aynen aldı̌̆ımız kısımlarda bu tercümeyi esas ittihaz etmekle beraber bazı deţişiklikjer yapmağı lüzumlu bulduk). 
ve müşterek kısmında muayyen veya günlük imkânlara göre değişen mahallere konulursa bir vedia karşsısnda bulunulưr.

Federal Mahkemé eskj içtihadını terketmesini şu mucip sebeblere istinad ettirmiştir ${ }^{174}$ :

"Her halükârda 490 mcı madde doğrudan doğruya tatbik edilemez, zira bu kanun hükmü kendilerine atların vesair koşum hayvanlarınn bakım ve muhafazalan terkedilmiş umumî ahır işletenleri istihdaf eylemek. tedir. Garajcı bu mânada ưmumî ahır işleten bir kimse değildir. Onun vaziyetinde koşum ve binek hayvanlannın bakm ve muhafazası karakteristik unsuru bulınmamaktadır. 490 mcı maddenin, umumi ahır işletenin mes'uliyetini koşum hayvanlariyla birlikte getirilen araba vesair teferruata da teşmil etmesi vakıass bu hükmün garajcılar hakkmda tatbikini müm-. kün kılmak için kâfi değildir, zira, ưmumì ahır işletenin mes'uliyetinin araba ve teferruatına teşmili münhasıran arabanın koşum hayvanlarmın bir fer'i olarak mülâhaza edilmesinden ve hukukan ayni muameleye tâbi tutulması zarurì bulunmasındandır. Halbuki asıl şey ile teferruat arasindaki böyle bir münasebet ọtomobiller için bilhassa mevcut degildir.

Fakat IBK. nun 490 mcı̣ maddesinin kıyasen dahi tatbiki düşünülemez. Mevzuubahs teșebbüslerin işletilmesi suretlerindeki ve iktisadì vaziyetlerindeki tehalüfe binaen böyle bir tatbik tatminkâr bir neticeye sevketmeyecektir. Garajlarm ve bilhassa otomobillerin müșterek tevdiinde mevzuubahs olan büyük garajlarm işletilmesi umumî bir ahımn basist işletmesinin aksine olarak, vazłhan sınaî vasfı haiz bir teşebbüstür ki hakkında IBK. nun 490 unc maddesi hükmü tatbik edilemez. Bu hükmün birinci fikrasına göre, umumi ahır işleten esas itibariyle kendisine tevdi edilen ai ve arabalarn sahibine ika edilmiş zarardan mes'uldür; fakat mes'uliyeti, ikinci flkra ile, kendisine veya müstahdemine kabili isnat bir kusur olmadikça her ayn hal için 1000 trank ile mahduttur. Mes'uliyetin bu súretle tahdidi, kanunun 1911 tadilâtı sırasında, otelciler için olduğu gibi umumi ahrr işletenler lehine de, bunlar üzerine terettüp eden mücerret illiyetten mütevellit mes'uliyetin çok ağır bir külfet olduğu mülâhazasıyła 'thal edilmişti. Binaenaleyh mes'uliyetin 1000 franklık tahdidi, otelcilerin ve umumi ahır işletenlerin mes'uliyetini tahammül edilebilir bir ölçüye getirebilecek ve bundan bașka 1000 . franktan dûn zararlar hakkında çok ağır olan mes'uliveti muayyen bir nisbette telâfi edebilecek bir hafifletme teşkil eylemiştir. Hükmün mâna ve gayesinden, 1000 frankın fevkinde bir

174) Not. 173 de zikri geçen $\mathrm{k}_{\mathrm{a}} \mathrm{rar}$, cons. 2. 
zarar ve ziyan talep eden müşteriye, otelcinin veya umumi ahır işletenin bir kusuru olduğunu ispat yükünün terettüp ettiği neticesi çıarılabilir.

Buna mukabil, garajcının otomobil sahibi ile münasebetinde te mes'uliyetin bu yolda tahdidini ne de fazlası için beyyine külfetinin yer değiştirmesini icap ettirecek hiçbir sebeb mevcut değildir. Garajcı öyle bir mütehassısdrr ki, kendisine tevdi edilen motörlü vastalann muhafazasın. dan ve münasip surette bakmmndan dolay, tam bir mes'uliyet deruhte etmesi, borçlunun kendisine hiç bir kusur isnad olunamayacağını ispa ${ }^{f}$ etmedikçe borcunun natamam ifasindan mütevellit zatardan mutlak surette mes'uliyetini âmir IBK. nun 97 nci maddesindeki umumì kaideye tevfikan, istenebilir. Diğer taraftan, garaj işletmenin bugünkü şekli nazara alınacak olursa garajcıların 1000franktan dûn zararlardan dolayı mücerret illiyet mülâhazasıyla mes'ul tutulmalannın sebebi anlaşlamamakta* dır. Fakat, herşeyden evvel, bir otomobilin kıymetinin umumiyet itibariyle 1000 frankı fazlasıyla aştığı gözönünde tutulacak olursa otomobil sahibine, zaran 1000 frankı tecavïz ettiğ her halde, garajcının veya müstahdem:nin bir kusur irikikâp ettiklerini ispat külfetini yüklemek ve bu suretle $\vdots_{3}$ pat edememe riskini ona tahmil etmek onu tasvibi imkânsız bir yük altına koymak olur. Otomobilini bir garaja tevdi eden bilâkis, onu sadece muhàfaza için değil ayni zamanda tamir ettirmek, ynkatmak, motörünü ayarlatmak üzere teslim ettiğ: takdirde olduğu gibi ve ayni ölçüde garajcının mes'ul olmasmı bekleyebilmelidir. Habuki bu gibi hallerde garajcomn mes'uliyetinin IBK. nun 97 nci maddesindeki umumî kaideye tâbi olduğunda şüphe yoktur. Bundan başka, ekser ahvalde bir otomobilin tevdii ayni zamanda onun tamiri, yıkanması ve motörünün kontrolü hususunda vekâleti de ihtiva ettiğinden, IBK. nun 490 mcı maddesinin tatbik sahasının sunırlandırılmasında ameli olarak haili hemen hemen imkânsız müşküllere maruz kahnması mümkündür, zira bir otomsbil hakkında temizlik ve tamir işleri, koşum hayvanlarnnn icap ettirdiği muhăaza ve ihtimam hususunda olduğu gibi vasıtanın tevdiine zarưi surette merbut değildir. Binaenaleyh IBK. nun 490 nncı maddesinin tatbik sahasını tayin zımnında tevdi mukavelesinin hüsnü ifası için garajcı tarafindan muavyen bir hizmetin yaplması gerekip gerekmediği vakıasına istinad edilemez."

Federal Mahkemenin kabul ettiği hal tarzı neticesinde otomobile arz olunan 1000 franktan aşă̆l zararlar için garajcmın, 1000 franktan yukarı olanlar için ise otomobil sahibinin vaziyeti iyileşmiştir. Filhakika, garajcı artık her halükârda hattâ zarar 1000 franktan aşağ bulunmadığını ispatla mes'uliyetten kurtulabilir; otomobil sahibi ise zara* rmın 1000 frankı aşan kısmının tazminini isteyebilmek için garajcının ku- 
surunu ispata mecbur değildir. Bu hal tarzı ve onun istinad ettiği mucip sebebler bize de kanaatbahş görünmekle beraber, hukukumuzda umumî garaj işetenler hakkında BK. md. $\mathbf{4 8 1}$ in tatbik edilmemesi ancak mezkúr hükümden IBK. nưn metninde mevcut olmayan "garaj" ve "otomobil" kelimelerinin ç̣karılmasıyla mümkündür.

Simdi mevzuumuz bakımindan assl mühim olan meseleye gelebiliriz: Ayni zamanda bir garajı olan otelci veya ahin bulunan hancı, yolculann beraberlerinde getirdikleri otomobil, binek ve koşum hayvanlan, araba ve. bunlann teferruatınin hasanndan, telefinden veya sirkatinden BK. md. 478 mucibince mi yoksa md. 481 e tevfikan mi mes'ul olur?

Bu mesele, Federal Mahkeme'nin içtihadını değiştirmesinden önceki Isviçre hukuku için daha ziyade nazarì bir ehemmiyet arzetmekte idi; bi. zim hukukumuz yönünden ise halen de vaziyet böyledir; zira ayni zamanda ahın veya garajı olan bir otele yolcunun koşum ve binek hayvanları, araba veya otomobil getirmesi takdirinde gerek BK. md. 478 in gerekse md. 481 in sartlan tahakkuk eder; keza mes'uliyetin neticeleri de her iki halde de aynidir. Halbuki Federal Mahkeme'nin yeni içtihadina göre otomobillerin umumî bir garaja konulması vedia vasfını taşıdığından, yol. cunun birlikte getirdiği otomobili otelin garajma bırakmasi da ayni mahiyette tavsif edilirse, otelcinin mes'uliyetinin şartlan ve neticeleri BK. md. 478 ve müt. tekinden çok farkl olacakhır: otelci, 1000 franktan aşağı zarar için de kusuru olmadığın ispatla mes'uliyetten kurtulabilecek, yolcunun da 1000 franktan fazla olan zaran için dahi otelcinin kusurunu ispat etmesine hacet kalmayacaktır.

Yakın zamanlara kadar Isviçre'de şarłhlerin ekseriyeti ${ }^{175}$ ve mahkemeler ${ }^{176}$, otelcinin garajina veya ahınna konulan otomobil, hayvanat, araba ve bunlarn teferruatı hakkında BK. md. 481 e tevfikan, yani umumî ahır veya garaj işleten sıfatıyla mes'ul olacağı kanaatindeydi; yalniz otomobil veya arabada brakılan ve onlarm teferruat mahiyetinde olma. yan eşya için gene otelcinin mes'uliyeti hakkmda ki BK. ind. 478 tatbik ediliyordu ${ }^{177}$. Chaubert ${ }^{178}$ ve Paul Buchli1 $7^{9}$ ise aksi fikri müdafaa edi-

175) Becker, Art. 487, Nr. 12; Art. 490, Nr. 4; Oser-Schönenberger, Art. 490, Nr. 2; Art. 487, Nr. 11; Schneider et Fick, Commentaire du Code fédéral des Obligations, 1 er volume, Neuehâtel 1915, Art. 490, no. 2; Rossel, sh. 564

176) Federal Mahkeme, 36 II 58, "Colteletti c. Hafen"

177) Paul Buchli'ye nazaran (sh. 50-51) Bk. md. 481, hayvanat, araba ve otomobilin teferruatı mahiyetinde olmaylp onların üzerinde veya içersinde israkılan eşyaya da teşmil edilmelidir. 1954 tarihli Beynelmilel otelcilik Nizamnamesi'nis bu hususla alâkah 8 inci maddesine tevfikan oteici, müşterilerin 
yorlardı; bu sonuncu müelliflere nazaran, otelciyi yolcunun bir kısım esyası için otelci ssfatıyla mes'ul tutmak mantığa aykırıdır; BK. md. 478 ve 481 den hangisinin tatbik olunacağı getirilen eşyanın mahiyetine göre değil, onu kabul eden şahsın meslekî sıfatına göre tayin olunur; büyük otellerin yolcularmon emrine bir garaj tahsis etmeleri, otel işletmesine gi. ren hizmetlerdendir; binaenaleyh, otelci, garajina ve ahırna konulan otomobil, araba ve hayvanlar için de BK. md. 478 e göre mes'ul tutulmalıdır. Federal Mahkeme de yeni karannda bu görüş̧e iltihak etmiştir180: "Indiği otel garajına müşteri tarafından bırakılmış otomobil kendisi tarafından beraberinde getirilen sair eşyadan mahiyet itibariyle farksızdır. Bu suretle otomobil, diğer eşya hakkında olduğu gibi, otelcinin himayesi altına girmektedir; binnetice IBK, nun 487 nci maddesi hükmünün otomobiller hakkında da tatbiki vacip olmaktadır. Umumî ahır işletenler için hususî bir mes'uliyet ihtiva etmemesine rağmen Alman hukukunda doktrin ve mahkeme içtihatlan da bu merkezdedir (Staudinger, 10 uncu tabı, BGB md. 701 şerhi, no. 6; Serlin, Wesen und Inhalt des Garagevertrages nach deutschem Recht, Diss. Bern 1939, sh. 52 ve müt). Mes'uliyetin 1000 frankla tahdidi bu gibi ahvalde hukuk hissini rencide edici mahiyette görünmemektedir. Garajcınm aksine olarak otelci meslek itibariyle otomobillerin muhafazasını deruhte eden bir mütehassss değildir; otelcilik muka. velesi çerçevesinde otomobillerin muhafazası seyyaha daha fazla kolaylık teminini istihdaf eden tâli bir eda teşkil eder. Buna binaendir ki, yolcu otelcinin kendisine karșı bir Garajcı gibi mes'ul tutulmasını bekleyemez. Kendi şahsî esbabı istirahati bakımından otomobilini otel garajına bırak. mıs olması itibariyle yolcunun riskin kir kısmını deruhte etmesi bilâkis hakkaniyet icabıdır. Fakat, otelci bakımundan, IBK. num 487 nci maddesine binaen mes'uliyetin tahdidi, otomobillerin yüksek kıymetleri ve yangin tehlikesinin bunlan maruz bıraktığı hususî risk sebebiyle, keṇdisı haddinden fazla ağır bir yük altmda bırakılmak istenmiyorsa mutlak su. rette zarurî bulunmaktadır."

Secrétan ${ }^{181}$, Federal Mahkeme'ce, yolculann otel garajina koyduk.

otelin garajında veya parking yerinde bulunan arabaları içine bıraktiklam eșyanın kaybından veya zarara uğramasından mes'ul değildir; eğer otel müstah. demleri, müşterinin talebi üzerine, onun otomobilini otelcinin müsaadesi olmaksızn bir garaja götürür veya oradan getirirlerse otelci otomobilin kayıp veya hasarndan da mes'ul tutulamaz.

178) Sh. 72.

179) Sh. 49.

180) Yukartda not 173 de zikri geçen karar, cons. 4 .

181) JaT, 1951, sh. 182-183. 
lan otomobiller jçin otelcinin alelâde bir müstevda gibi değil de BK. md. 478 mucibince mes'ul saylmasinı tenkit etmektedir ${ }^{182}$. Ona nazaran, büyük otellerin garajlan, tesisat, müstahdemin ve emniyet tedbirleri bakimundan, umumi garajlarmkinden hiç de aşağ̀ kalmayan bir teşkilâta sahiptir; binaenaleyh ofelciler de yolculann otomobilleri bakmmndan garajclar gibi umumì hükü̈mlere tevfikan mes'ul tutulmaldır. Hattâ Secrétan; bir adım daha ileriye giderek, yolcunun otomobiliyle sair esyası arasında. bir fark gözetilmemesi için, otelcinin bütün esya hakkında umumì hükümlere binaen mes'uliyeti cihetine gidilmesini teklif eylemiştir.

Kanaatimizce, otelcinin mes'uliyetine mütealiik hususì hükümler bir zaruretin ifadesi olup bunlan kaldırmak doğru olmaz ${ }^{183}$. Bizim müdałaa. ettiğimiz gibi, otelcinin mes'uliyetine konulan 100 liralk ấzamî hadden sarfınazar edilirse, otelçinin, yolcunun otomobili için de BK. md. $478 \mathrm{mu}$ cbince mes'ul olmasında bir mahzur kalmaz. Filhakika Federal Mahkeme'yi garajclann mes'uliyeti hakkmda artk IBK. md. 490 1 tatbik etmemeğe sevkeden en mühim âmil bu hükümde de 1000 franklik âzamî had. din mevcut bulunmast, halbuki bugün otomobillerin çok daha fazla kiymet taşıması olmuştur. Gene kanaatimizce, BK. md. 481 (IBK. md, 490) de de 100 lirahk âzamî had kaldınlrrsa, umumî garajclann mes'uliyetini halen olduğu gibi bu hükme tâbi bırakmak, Federal Mahkeme'nin yaptı̆gr gibi umumî hükümlere müracaat etmekten daha isabetli olur; zira umumî garajlarda da muhtelif şahslarn girip çikması dolayısyla otel işletmesindekine benzeyen riskler ve ispat zorluklan mevcuttur.

182) Ayni fikirde Pétermann, sh. 6-7.

183) Bk. yuka1da $I, 1, a$, in fine. 